\title{
The Distribution of Material Footprints in Germany
}

\author{
Frank Pothen* $\quad$ Miguel Angel Tovar Reaños ${ }^{\dagger}$
}

February 21, 2018

Hannover Economic Papers (HEP) No. 627

ISSN 0949-9962

\begin{abstract}
This study investigates the within-country heterogeneity of material footprints implied by households' consumption in Germany. Material footprints are defined as the amount of biomass, minerals, and fossil fuels extracted to produce the goods that households consume. Combining input-output data with households' consumption expenditures from the German sample survey of income and expenditure (EVS), we present the first comprehensive study on the distribution of material footprints among households, highlighting hot spots of unsustainable consumption patterns by household groups. Households in the quartile with the highest consumption expenditures have material footprints three times as large as those in the quartile with the lowest expenditures. Results of a microeconomic model of household's consumption behaviour estimated on the EVS data suggest that price-based instruments can reduce material footprints of luxury consumption such as leisure and private transport without imposing large burdens on low-affluence households. The material footprints caused by energy consumption do not react sensitively to price changes, suggesting that non-price policies are more effective to reduce them.
\end{abstract}

Keywords: material footprint, demand system estimation, input-output analysis, sustainable consumption

${ }^{*}$ Leibniz University of Hanover, Institute for Environmental Economics and World Trade, 30167 Hannover, Germany, email: pothen@iuw.uni-hannover.de. We thank Tomer Fishman, Heinz Welsch, Christiane Reif, Dirk Rübbelke, Michael Hübler, Florian Flachenecker, Tamar Lichtman as well as seminar participants at Hannover, Freiberg, and Heidelberg for their valuable feedback on earlier versions of this study. Frank Pothen gratefully acknowledges support by the Lower Saxony Ministry of Science and Culture through the 'Niedersächsisches Vorab' grant programme (grant ZN3043). Miguel A. Tovar is grateful for financial support of the German Federal Ministry of Education and Research (FKZ 01UT1411A). Further details can be obtained from http://kooperationen.zew.de/en/intrans/home.html.

${ }^{\dagger}$ Centre for European Economic Research, Environmental and Resource Economics, Environmental Management, 68161 Mannheim, Germany, email: tovar@zew.de 


\section{Introduction}

In 2011, the European Commission introduced its flagship initiative "A resource-efficient Europe" (EU Commission, 2011a) as part of the Europe 2020 growth strategy. It aims at "[developing] our wealth and well-being, whilst reducing the levels and impact of our resource use" (EU Commission, 2011b). Europe's ambitions are shared by a number of countries, including Japan and China, which strive to use materials more efficiently or to reduce the level of material use altogether (Bahn-Walkowiak and Steger, 2015). These goals are motivated by the local and global pollution caused by the extraction and processing of materials (Dudka and Adriano, 1997; Csavina et al., 2012; Rooney et al., 2012; Brandt et al., 2014) as well as by a notion that humanity's material use as a whole has reached unsustainable levels (Hoekstra and Wiedmann, 2014). Concerns about supply disruptions with economically important raw materials further motivate these policies (U.S. Department of Energy, 2011; EU Commission, 2014a).

From a sustainability perspective, the material footprint (MF), also known as raw material consumption (RMC), is an advantageous indicator to inform decision makers about material use. It is defined as the sum of all materials extracted to produce a country's or household's final demand along the supply chain, irrespectively of where the materials have been used. ${ }^{1}$ Unlike indicators of direct material use such as the domestic material consumption (DMC), which records domestically extracted plus imported minus exported materials, the MF does not falsely indicate dematerialisation if a country offshores material-intensive production. This property is particularly important for resource-poor countries which depend heavily and increasingly (Wiedmann et al., 2015) on direct as well as indirect imports of materials. Acknowledging these properties, the EU Commission proposes GDP divided by the material footprint as an indicator for resource productivity (EU Commission, 2014b).

Discouraging the consumption of material-intensive goods by households in wealthy nations can contribute to reducing the ecological damages caused by the extraction and processing of raw materials. Designing the corresponding policies necessitates data on the amount of biomass, minerals, and fossil fuels used to produce commodities for final consumption and hinge on evidence on how households' material footprints react to incentives, in particular prices. While existing literature provides estimates for countries' material footprints (Muñoz et al., 2009; Schoer et al., 2012; Arto et al., 2012; Bruckner

\footnotetext{
${ }^{1}$ A country's MF is usually computed by combining monetary input-output tables with material extraction data in physical units (Lutter et al., 2016).
} 
et al., 2012; Wiebe et al., 2012; Kovanda and Weinzettel, 2013; Schaffartzik et al., 2014; Wiedmann et al., 2014; Giljum et al., 2015; Wiedmann et al., 2015; Ivanova et al., 2015; Wenzlik et al., 2015; Giljum et al., 2016) ${ }^{2}$, evidence on the heterogeneity of households' MF within a country is scarce and, furthermore, either focused on exotic materials such as neodymium (Shigetomi et al., 2015, 2016) or based on very small samples (Kotakorpi et al., 2008; Lettenmeier et al., 2012). ${ }^{3}$

This study makes two contributions to a better understanding of households' material footprints. First, it estimates the distribution of material footprints among German households, highlighting hot spots of material-intensive consumption. It considers 36 household groups distinguished by socio-economic characteristics as well as 10 consumption categories. To our knowledge, it constitutes the first comprehensive study on the within-country distribution of households' material footprints.

The second contribution of this study is to estimate how households' material footprints react to changes in prices and affluence. Data on material footprints' responsiveness to price changes indicates whether price-based instruments such as taxes can effectively curb material footprints. Considering different household groups, furthermore, allows to design policies that avoid undesirable burdens for low-affluence households. This study is the first to quantify how households' MF react to price and affluence.

Our research is conducted in two steps. First, we estimate material footprints per monetary unit of consumption by using the Exiobase global multi-region input-output model (Tukker et al., 2013; Wood et al., 2014) and link them to households' consumption expenditure data from the German sample survey of income and expenditure (Einkommensund Verbrauchsstichprobe, EVS). ${ }^{4}$ Expenditures, thus, serve as the measure of affluence in this study.

Second, we employ the exact affine Stone index (EASI, Lewbel and Pendakur, 2009) demand system to model households' consumption behaviour. It represents consumption decisions as a system of equations which depend on prices, consumption budgets, and observed as well as unobserved household characteristics. We employ the EASI demand

\footnotetext{
${ }^{2}$ Utilising between-country heterogeneity, studies find affluence, measured as income or final demand, to be the principle driver of material footprints (Wiedmann et al., 2015; Pothen, 2017; Pothen and Welsch, 2017)

${ }^{3}$ The energy footprint of households, also known as energy requirements, has been estimated since the 1970s (Herendeen and Tanaka, 1976; Herendeen, 1978). Other studies on energy and carbon footprints of households include Wier et al. (2001) for Denmark, Weber and Matthews (2008) for the USA, Druckman and Jackson (2009) and Baiocchi et al. (2010) for the UK, Girod and De Haan (2010) for Switzerland, Steen-Olsen et al. (2016) for Norway, and Lenzen et al. (2006) for Australia, Brazil, Denmark, India as well as Japan. Hertwich (2005) provides an overview.

${ }^{4}$ Due to higher data quality, the MF only considers materials which enter consumption and production processes. Unused extraction, such as overburden in mining, is not considered.
} 
system because it extends previous models of household demand (Deaton and Muellbauer, 1980; Banks et al., 1997) by allowing for a non-linear relationship between budget and demand. This flexibility is advantageous in the light of the close and potentially non-linear relationship between affluence and material footprints found on the country-level (Pothen and Welsch, 2017). Demand systems have been used to study households' energy use and carbon emissions (Baker et al., 1989; Creedy and Sleeman, 2006; Labandeira et al., 2006; Pashardes et al., 2014; Sommer and Kratena, 2017; Tovar Reaños and Wölfing, 2018) but, to our knowledge, this is the first study employing a demand system to investigate material footprints. It is, furthermore, the first to use the EASI demand system to study sustainable consumption. We use the EVS waves of 1993 to 2013 which contain 122,500 observations.

Germany, the world's fourth-largest economy, is investigated in this study because it depends on material imports and its government has implemented a target of doubling material productivity by 2020 compared to 1994 (Bundesregierung, 2002; Bahn-Walkowiak and Steger, 2015). Our results suggest a right-skewed distribution of MF among households in Germany. Material footprints exceed $100 \mathrm{t}$ in almost one per cent of them. The quartile of households with the lowest expenditures has material footprints one third of the size of those in the quartile with the highest expenditures. While transport, leisure, and appliances are particularly important for high-affluence households' MF, food, housing, and energy account for a substantial share of all households' material footprints. Price-based instruments can effectively reduce material footprints; equity issues, however, should be also considered. While price increases for housing and food can lead to substantial reductions in MF, they are likely to impose a disproportional burden on low-affluence households. Results in this paper are presented for materials aggregated according to their physical mass. We, furthermore, provide detailed results for 45 individual materials. These enable researchers to study footprints of specific materials or to use alternative aggregating schemes (Fang and Heijungs, 2014), such as monetary measures of environmental damages, to weigh materials. The results for individual materials are available in the online appendix. We present the material footprint of copper as an example in appendix B.

The paper proceeds as follows. Section 2 presents the methodological approach. The results are shown in section 3. Section 4 discusses policy implication of our results. Section 5 concludes. 


\section{Methodology}

\subsection{Computing the Material Footprints}

Let $\overline{\mathbf{M}} \mathbf{F}$ denote the matrix of material footprints per monetary unit of consumption. Each element $M F_{m, j, s}$ records the amount of material $m$ which is extracted to manufacture one euro worth of product $j$ in region $s$. By using a global multi-region input-output (GMRIO) table, $\overline{\mathbf{M}} \mathbf{F}$ can be computed as follows (Miller and Blair, 2009):

$$
\overline{\mathbf{M}} \mathbf{F}=\mathbf{E} \cdot \mathbf{L}
$$

$\mathbf{E}$ is the matrix of material intensities. Its elements $E_{m, i, r}$ record how many kilograms of material $m$ are extracted to produce one euro worth of product $i$ in $r$. $\mathbf{L}$ is the Leontief inverse. Each element $L_{i, r, j, s}$ records how many euros worth of product $i$ from $r$ are used to manufacture one euro of product $j$ in $s$. The Leontief inverse accounts for all inputs of product $i$ from $r$ over the whole supply chain. It is computed as $\mathbf{L}=(\mathbf{I}-\mathbf{A})^{-1}$, where A denotes the matrix of direct input coefficients and $\mathbf{I}$ the identity matrix of appropriate size.

We use the Exiobase product-by-product GMRIO table (Wood et al., 2014; Tukker et al., 2013) to compute L. It differentiates between 200 products and 48 regions. 43 thereof represent individual countries, the remaining five are rest-of-the-world aggregates. ${ }^{5}$ The Exiobase's base year is 2007. Furthermore, it contains material intensities $\left(E_{m, i, r}\right)$ for 45 individual materials.

Input-Output tables record consumption expenditures differently than household surveys like the German sample survey of income and expenditure (EVS). The former differentiate between products (cars, refined petroleum) while the latter record expenditures on functionally defined consumption purposes such as transport. We index these consumption purposes $c$ and $c c$ throughout the paper. Household surveys, furthermore, measure expenditures in purchasers' prices, including net taxes and trade margins ${ }^{6}$ while input-

\footnotetext{
${ }^{5}$ Due to its high resolution, in particular in primary products, the Exiobase is well suited for computing material footprints. Other GMRIO tables which could be used to compute material footprints include the World Input-Output Database (WIOD; Timmer, 2012; Dietzenbacher et al., 2013; Timmer et al., 2015) and EORA (Lenzen et al., 2013). The GTAP (Global Trade Analysis Project; Aguiar et al., 2016; Narayanan et al., 2012) can also be converted into a GRMIO table (Andrew and Peters, 2013). We choose the Exiobase because it offers the highest resolution of products. Schoer et al. (2013) rely upon a hybrid approach to compute material footprints for the European Union. They combine a European Input-Output model with life cycle assessment data to fill in gaps for goods which are not produced in Europe. Their data is only available for Europe as a whole, however.

${ }^{6}$ Unlike many other countries, German national accounts do not record transport margins. Transport services are accounted for as inputs into production.
} 
output tables are usually recorded in basic prices (excluding net taxes and trade margins). The matrix of per-euro material footprints $\bar{M} \mathbf{F}$ is adjusted to match the expenditure data from the EVS (see e.g. Steen-Olsen et al., 2016, for a description of the principles of matching footprints with household expenditure data). We, furthermore, add the material footprints associated with the use of residential dwellings. The details of this process are presented in appendix A. Multiplying the adjusted matrix $\overline{\mathbf{M}} \mathbf{F}$ with a household's expenditures yields its material footprint. The microeconomic model of consumer behaviour then indicates how this material footprint depends on prices, expenditure budgets, and socio-demographic characteristics.

\subsection{Modelling Household Behaviour}

The exact affine Stone index (EASI; Lewbel and Pendakur, 2009; Pendakur, 2009) demand system is used to model household consumption behavior. It rests on the assumption that households choose an optimal mix of commodities given their budget constraints. It yields a system of equations in which each equation represents a budget share $w_{c}$, the fraction of its budget that a households spends on a specific $c$. Providing a first-order approximation of an arbitrary expenditure function, the EASI is the latest major advancement in the literature on household demand systems. The EASE extends its predecessors (Deaton and Muellbauer, 1980; Banks et al., 1997) by allowing for a non-linear relationship between expenditure and expenditure budget (the Engels curves).

In order to estimate the EASI, only information on expenditures by consumption purpose $(C(p, y))$, on their prices, and on demographic characteristics is required. Its starting point is the following approximation to the households' expenditure function (Lewbel and Pendakur, 2009):

$$
\begin{aligned}
\log [C(p, y)]= & y+\sum_{c} m_{c}(y, z) \log \left(p_{c}\right)+\frac{1}{2} \sum_{c} \sum_{c c} \alpha_{c, c c} \log \left(p_{c}\right) \log \left(p_{c c}\right)+ \\
& \frac{1}{2} \sum_{c} \sum_{c c} \zeta_{c, c c} \log \left(p_{c}\right) \log \left(p_{c c}\right) y+\sum_{c} \epsilon_{c} \log \left(p_{c}\right)
\end{aligned}
$$

where $p_{c}, p_{c c}$ are the prices of consumption purposes $c$ and $c c . y$ is the implicit household utility, the maximum utility which a household can attain with a given budget $X . m_{c}$ is a function which specifies the model. $\epsilon_{c}$ represents unobserved preference heterogeneity. We follow Lewbel and Pendakur (2009) who choose the following specifications for $y$ and 
$m_{c}$ :

$$
\begin{aligned}
& y=\frac{\log (X)-\sum_{c} w_{c} \log \left(p_{c}\right)+\frac{1}{2} \sum_{c} \sum_{c c} \alpha_{c, c c} \log \left(p_{c}\right) \log \left(p_{c c}\right)}{1-\frac{1}{2} \sum_{c} \sum_{c c} \zeta_{c, c c} \log \left(p_{c}\right) \log \left(p_{c c}\right)} \\
& m_{c}=\sum_{u=0}^{U} \beta_{c, u} \log (y)^{u}+\sum_{l} \gamma_{c, l} \log (y) z_{l}+\sum_{l} \delta_{c, l} z_{l}
\end{aligned}
$$

A polynomial function of degree $u \in 1, \ldots, U$ represents the impact of the expenditure level on budget shares $w_{c} \cdot{ }^{7} z_{l}, l=1, \ldots, L$, are demographic characteristics such as the age of the household head. $\alpha_{c, c c}, \beta_{c, u}, \gamma_{c, l}, \delta_{c, l}$, and $\zeta_{c, c c}$ are the parameters to be estimated. This specification allows for highly flexible Engel curves while keeping the functional form comprehensible. Applying Shephard's lemma to expression (2) and using equations (3) and (4), the following set of equations for the budget shares $w_{c}$ are obtained:

$$
\begin{aligned}
w_{c}= & \sum_{u=0}^{U} \beta_{c, u} \log (y)^{u}+\sum_{c c} \alpha_{c, c c} \log \left(p_{c c}\right)+\sum_{l} \delta_{c, l} z_{l}+ \\
& \sum_{l} \gamma_{c, l} \log (y) z_{l}+\sum_{c c} \zeta_{c} \log \left(p_{c c}\right) y+\epsilon_{c}
\end{aligned}
$$

The right-hand side of equation (5) captures the effects of expenditure levels, prices, and preferences on budget shares $w_{c}$. The coefficients $\beta_{c, u}$ measure the influence of expenditure levels on budget shares, determining the shape of the Engel curves. $\alpha_{c, c c}$ quantifies the effect of prices on budget shares. The coefficients $\delta_{c, l}$ are demographic demand shifters, representing the impact of household properties such as the number of children. $\gamma_{c, l}$ and $\zeta_{c}$ are interaction effects between implicit utility $y$ as well as socio-demographics and prices. ${ }^{8}$

A non-linear generalized method of moments (GMM) estimator or an iterated linear approximation can be used to estimate the demand system. We follow Lewbel and Pendakur (2009) and use the iterated three-stage least squares (3SLS) estimator which is less computationally demanding than the GMM estimator.

Once the parameters in equation 5 are estimated, own-price elasticities $\left(O P E_{c}\right)$, cross-

\footnotetext{
${ }^{7}$ The system is estimated with a polynomial of order four $(U=4)$ in the term $\sum_{u} \beta_{c, u} \log (y)^{u}$ in Equation (5). This is the highest degree that appears to be statistically relevant.

${ }^{8}$ The following restrictions ensure the theoretical consistence of the estimated expenditure function:

$$
\sum_{c c} \alpha_{c, c c}=\sum_{c} \alpha_{c, c c}=\sum_{c} \zeta_{c}=\sum_{c} \beta_{c, u}=0, \sum_{c} \gamma_{c, l}=\sum_{l} \delta_{c, l} z_{l}=0, a_{c, c c}=a_{c c, c}
$$

Note that $\sum_{c} \beta_{c, u}=0$ must hold only for $u \neq 0$ and $\sum_{c} \beta_{c, 0}=1$ 
price elasticities $\left(C P E_{c c, c}\right)$, and expenditure elasticities $\left(E E_{c}\right)$ can be computed as follows:

$$
\begin{aligned}
O P E_{c} & =\left\{\frac{\partial w_{c}}{\partial \log \left(p_{c}\right)}\right\} \frac{1}{w_{c}}-1 \\
C P E_{c c, c} & =\left\{\frac{\partial w_{c}}{\partial \log \left(p_{c c}\right)}\right\} \frac{1}{w_{c}} \\
E E_{c} & =\left\{\frac{\partial w_{c}}{\partial \log (X)}\right\} \frac{1}{w_{c}}+1
\end{aligned}
$$

The German Einkommens- und Verbrauchsstichprobe (survey of income and expenditure, EVS) is used to estimate the EASI demand system. It provides information on expenditures across goods, expenditure, and other socio-economic variables. The EVS is a voluntary survey conducted by the German Statistical Office. Participants are interviewed at the beginning and at the end of the survey to ensure coherence in the reported information. In addition, a rotation procedure is used where households are followed across a short period of time to provide consistency of the reported data across time. The survey is carried out every five years. We use the waves 1998, 2003, 2008 and 2013 for the econometric estimation which provide us with 122,500 observations. To carry out our simulation exercise on footprint reaction to household prices and income we use the wave 2008 which is the closest year to the macro footprints depicted in the previous section. The sample size of this wave comprises 44,088 households.

Lewbel (1989)'s methodology is used to obtain household-specific prices by combining the micro data with prices reported by the German Statistical Office. Table 9 in appendix C provides descriptive statistics of the variables used in the estimation.

We aggregate the EVS's consumption purposes into ten consumption purposes which roughly correspond to the two-digit COICOP (Classification of Individual Consumption According to Purpose) classification. They are sufficiently detailed to reveal the consumption purposes' importance for MF while avoiding multiple zeros in the reported budget shares which pose a challenge to the estimation procedure. Table 1 shows the correspondence between the three-digit COICOP classification and the consumption purposes used in this study. We distinguish between ten consumption purposes $c$ : food, beverages, tobacco, narcotics (Food); clothing and footwear (Clothing); housing excluding electricity and heating (Housing); electricity and heating (Energy); furnishings, household equipment and routine household maintenance (Appliances); transport including the purchase of cars (Transport); communication (Communication); health, education, and personal care (Health \& Edu); recreation and culture (Leisure); other goods (Others).

Household types are distinguished according to two criteria. First, we differentiate 
four expenditure quartiles. Second, we distinguish households by their size and the age of the household head. These groups are as follows: single +65 (above 65 years), single no children, single with children, 2 adults +65 no children, 2 adults no children, 2 adults one child, 2 adults two children, other households.

An equivalence scale is used to make households of different sizes comparable. It reflects that a household with three members does not require three times as many resources as a single household. We report values based on the square root of household size as in Grösche and Schroder (2014). ${ }^{9}$ Additionally, we use weights derived from macroeconomic data to correct for under-reporting in the survey data.

\footnotetext{
${ }^{9}$ Alternatively, we have used the modified OECD equivalence scale in which a factor of 1 is used for the first adult and a factor of 0.5 for each additional adult. For every child, a factor of 0.3 is added. The choice of the equivalence scale has no major impact on our results.
} 


\begin{tabular}{|c|c|c|}
\hline COICOP & Description & $c$ \\
\hline 01.1 & Food & Food \\
\hline 01.2 & Non-alcoholic beverages & Food \\
\hline 02.1 & Alcoholic beverages & Food \\
\hline 02.2 & Tobacco & Food \\
\hline 03.1 & Clothing & Clothes \\
\hline 03.2 & Footwear & Clothes \\
\hline 04.1 & Actual rentals for housing & Housing \\
\hline 04.2 & Imputed rentals for housing & Housing \\
\hline 04.3 & Maintenance and repair of the dwelling & Housing \\
\hline 04.4 & Water supply & Housing \\
\hline 04.5 .1 & Electricity & Energy \\
\hline 04.5 .2 & Gas & Energy \\
\hline 04.5 .3 & Liquid fuels & Energy \\
\hline 04.5 .4 & Solid fuels & Energy \\
\hline 04.5 .5 & Heat energy & Energy \\
\hline 05.1 & Furniture and furnishings & Appliances \\
\hline 05.2 & Household textiles & Appliances \\
\hline 05.3 & Household appliances & Appliances \\
\hline 05.4 & Glassware, tableware, and household utensils & Appliances \\
\hline 05.5 & Tools and equipment for house and garden & Appliances \\
\hline 05.6 & Goods and services for household maintenance & Appliances \\
\hline 06.1 & Medical products, appliances and equipment & Health \& Edu \\
\hline 06.2 & Outpatient services & Health \& Edu \\
\hline 06.3 & Hospital services & Health \& Edu \\
\hline 07.1 & Purchase of vehicles & Transport \\
\hline 07.2 & Operation of personal transport equipment & Transport \\
\hline 07.3 & Transport services & Transport \\
\hline 08.1 & Postal services & Communication \\
\hline 08.2 & Telephone and telefax equipment & Communication \\
\hline 08.3 & Telephone and telefax services & Communication \\
\hline 09.1 & Information processing equipment & Leisure \\
\hline 09.2 & Other major durables for recreation & Leisure \\
\hline 09.3 & Other recreational items and equipment & Leisure \\
\hline 09.4 & Recreational and cultural services & Leisure \\
\hline 09.5 & Newspapers, books, and stationery & Leisure \\
\hline 09.6 & Package holidays & Leisure \\
\hline 10 & Education & Health \& Edu \\
\hline 11.1 & Catering services & Leisure \\
\hline 11.2 & Accommodation services & Leisure \\
\hline 12.1 & Personal care & Health \& Edu \\
\hline 12.3 & Personal effects nec ${ }^{10}$ & Health \& Edu \\
\hline 12.4 & Social protection & Health \& Edu \\
\hline 12.5 & Insurance & Others \\
\hline 12.6 & Financial services nec & Others \\
\hline 12.7 & Other services nec & Others \\
\hline
\end{tabular}

Table 1

Correspondence between COICOP categories and consumption purposes $(c)$

\section{Results}

\subsection{Distribution of Material Footprints}

Figure 1 shows the distribution of material footprints among German households in 2008.

The horizontal axis represents the MF in metric tons (t), truncated at 100 tons. To make households of different sizes comparable, their MF is divided by the square root of the 
number of household members. This equivalisation is applied throughout the study. The vertical axis represents density, the share of households whose MF falls into an interval.

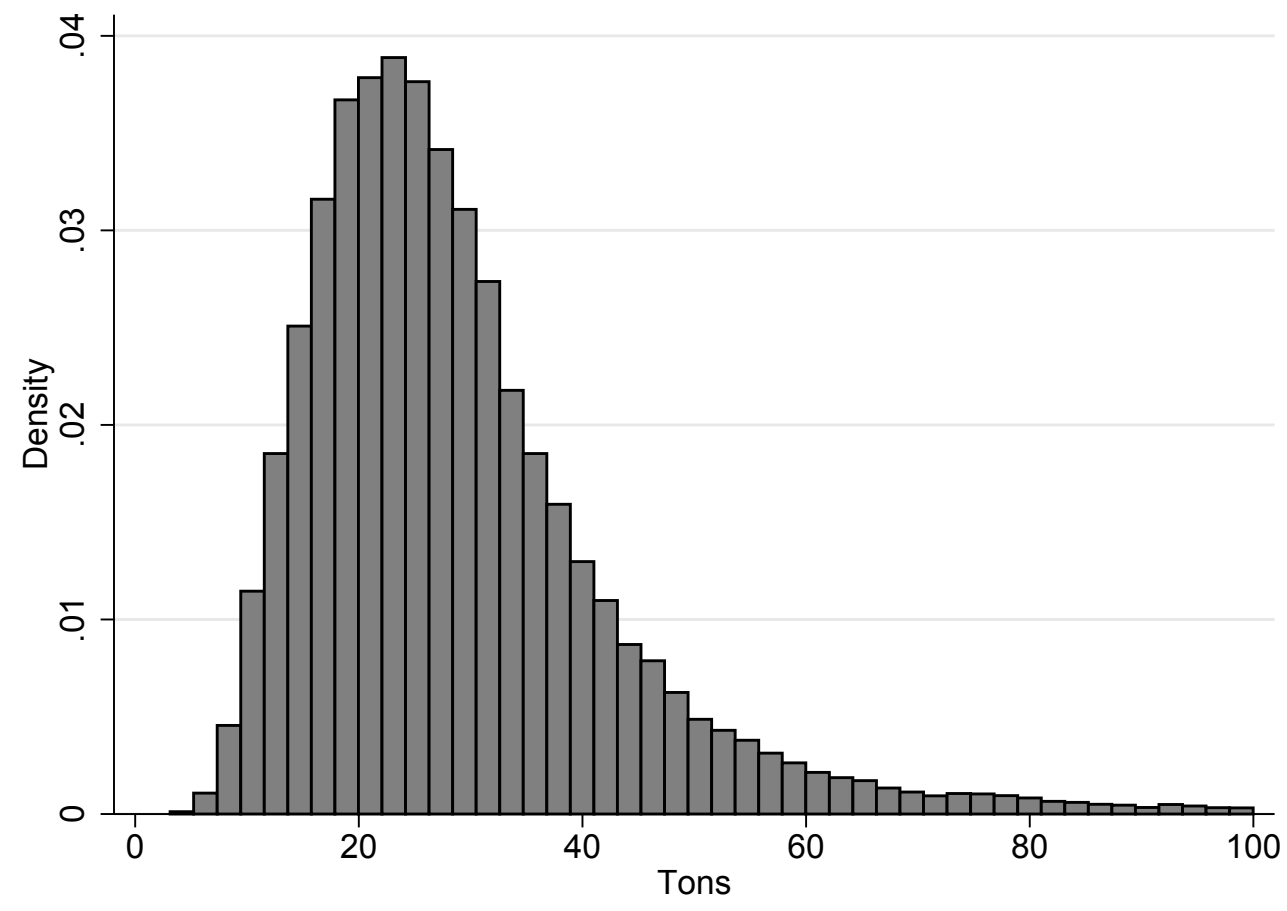

Figure 1

Distribution of households' material footprints in Germany

The distribution is truncated at a MF of $100 \mathrm{t}$ in this figure.

The average MF of an equivalised German household in 2008 was 26.99 t, with a standard deviation of $16.44 \mathrm{t}$. The distribution of material footprints is highly rightskewed (skewness: 3.63) and exhibits notable outliers: while $95.57 \%$ of all households have a material footprint of less than 60 tons, $0.87 \%$ exhibit a MF of more than 100 tons.

The average material footprint in tons for household groups differentiated by expenditure quartile and socio-demographic characteristics (household size, age of the household head) is displayed in table 2. Differences in MF among socio-demographic groups are notable. Households with children exhibit below-average MF while singles without children exhibit above-average MF, in particular if the household head is retired. Material footprints, nevertheless, grow in expenditure for all socio-demographic groups. The average MF of households in the last quartile (49.29 t) is more than three times as big as in the first quartile $(16.15 \mathrm{t})$. Comparing these numbers to the consumption expenditures displayed in table 8 in appendix $\mathrm{C}$ reveals that material footprints grow almost proportionally to expenditures for all socio-demographic groups.

One limitation that this study shares with most of the existing literature on the estimation of household's footprints is that combining material footprints (in our case) or 


\begin{tabular}{lcccc}
\hline \hline & \multicolumn{4}{c}{ Quartile } \\
& 1 & 2 & 3 & 4 \\
\hline All households & 16.15 & 24.26 & 30.38 & 49.29 \\
Single retired & 17.75 & 30.53 & 44.17 & 71.81 \\
Single no children & 16.33 & 29.82 & 42.93 & 79.15 \\
Single with children & 13.93 & 20.28 & 28.43 & 51.77 \\
2 adults head retired & 15.96 & 23.48 & 32.55 & 55.73 \\
2 adults no children & 15.20 & 23.22 & 32.26 & 56.32 \\
2 adults one child & 13.14 & 19.41 & 26.74 & 43.98 \\
2 adults two children & 11.78 & 16.60 & 22.99 & 36.89 \\
Other households & 14.31 & 20.15 & 26.44 & 43.47 \\
\hline \hline
\end{tabular}

Table 2

Material footprints by household group in $\mathrm{t}$

Material footprints by household groups distinguished by expenditure quartile (columns) and sociodemographic characteristics (rows). Households are equivalised, results are presented in metric tons.

$\mathrm{CO}_{2}$ emission factors (as in most of existing studies) per monetary unit of consumption with monetary expenditure data can overestimate the impact of affluence. When their expenditures rise, households might not simply increase their demand but shift it towards higher-quality goods. Assuming a constant material-intensity for goods of different quality overestimates material footprints if high-quality goods are produced with more labour rather than more material inputs. Using functional units ( $\mathrm{kg}$ of rice, number of dishwashers) instead of expenditure, Girod and De Haan (2010) find that Swiss households' expenditure elasticity of greenhouse gas emissions, the percentage change of greenhouse gas emissions in response to a one per cent increase in expenditure, declines from 1.06 to 0.53. Furthermore, the material footprints of similar goods can vary substantially (Cederberg and Mattsson, 2000). The proportional relationship between affluence and MF suggested by our methodology should be interpreted as an upper-bound estimate.

Our study distinguishes between ten consumption purposes $(c)$, groups of products which serve a common function: food, housing, energy, transport, communication, clothing, health and eduction ${ }^{11}$, appliances, and other goods. ${ }^{12}$ Figure 2 presents their budget shares, the fractions of the budget spent on each $c$, by expenditure quartile. It shows that the budget shares of food, housing, energy, and communication fall in expenditure levels while those of the remaining consumption purposes rise. A conspicuous increase in the

\footnotetext{
${ }^{11}$ The consumption purpose health and education encompasses expenditures on medical services, beauty products, and educational services which are paid for by the households themselves.

${ }^{12}$ The classification is based on the United Nations' Classification of Individual Consumption According to Purpose (COICOP). Table 1 displays the correspondence between the three-digit COICOP classification used in the EVS and the ten consumption purposes.
} 
budget share of transportation between the third and the fourth quartile $(+44.32 \%)$ can be observed, which is driven by the purchase of vehicles.

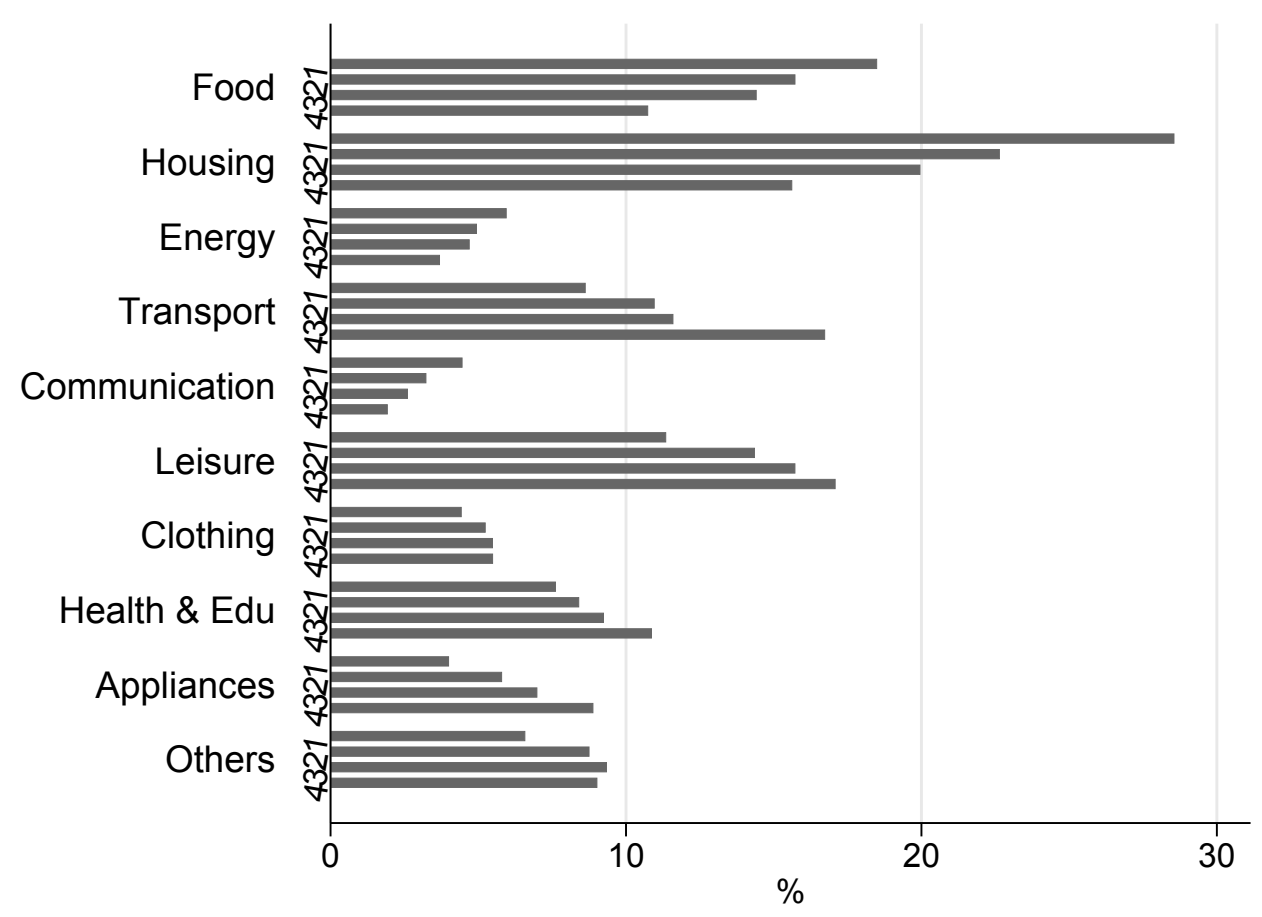

Figure 2

Budget shares of consumption purposes by expenditure quartile in per cent

Budget shares measure the fraction of expenditures allocated to each consumption purpose. The numbers indicate the expenditure quartile.

The composition of budgets is important for the distributive effects of price-based policies. If, for instance, energy is taxed to reduce material footprints, a larger burden is imposed on low-affluence than on high-affluence households because the former devote a larger fraction of their budget to energy.

Figure 3 displays households' average material footprint due to each $c$ in tons by expenditure quartile. They all grow in expenditure, even for those consumption purposes whose budget shares decline. Falling budget shares, thus, do not compensate for increasing expenditure levels. Material footprints due to leisure, health and education, and appliances rise substantially between the third and the fourth quartile. The largest increase is found for the MF due to transport. It jumps from 3.73 tons in the third quartile to 10.31 tons in the fourth. This rise is caused by high expenditures on transport, indicated by figure 2, and a shift from public transportation to material-intensive cars. 


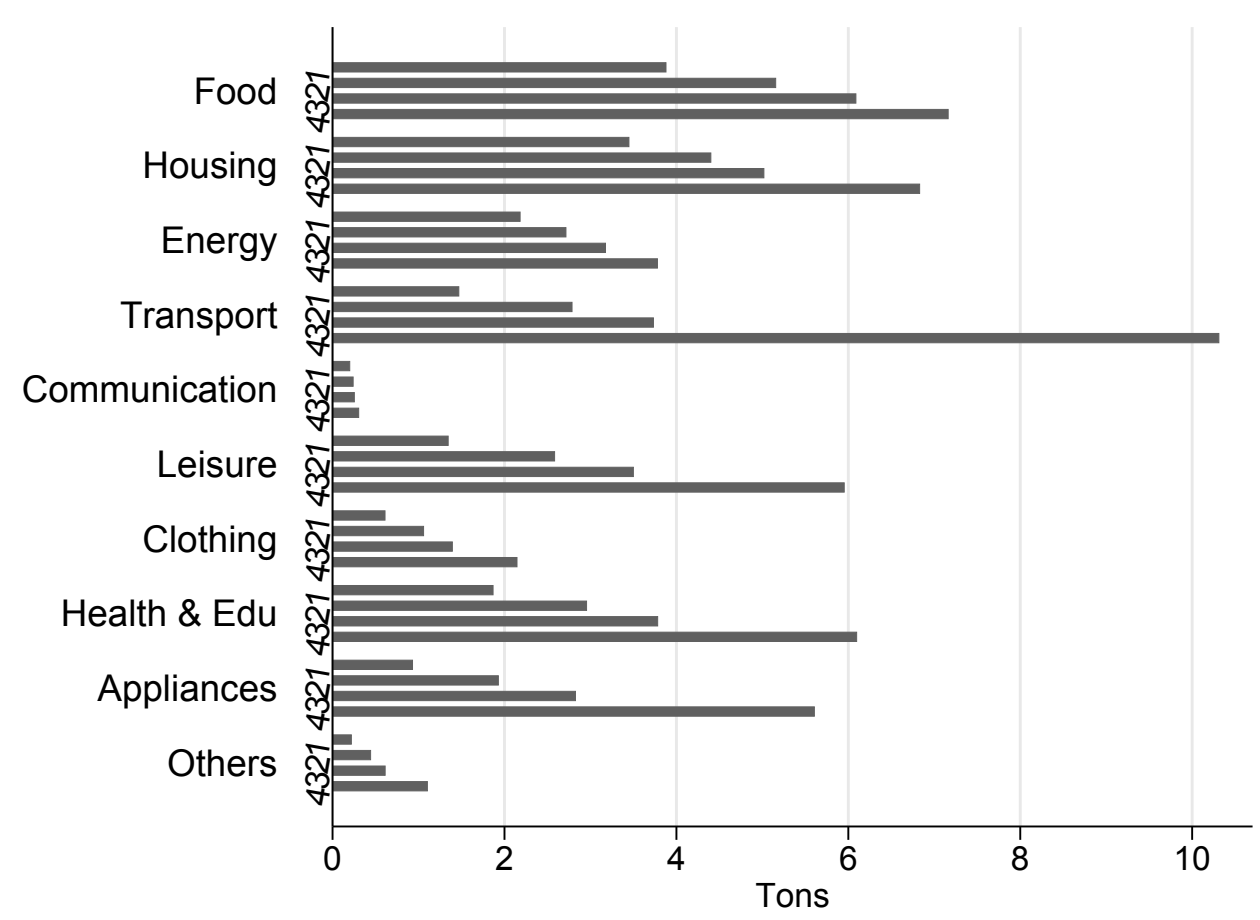

Figure 3

Material footprints due to consumption purposes by expenditure quartile in $t$

Average material footprint due to each consumption purpose for equivalised households. The numbers indicate the expenditure quartile.

\subsection{Demand Responses to Price and Budget Changes}

This subsection shows how consumption reacts to price and budget changes. Table 3 presents the estimated own-price elasticities $\left(O P E_{c}\right)$, the percentage changes in demand for each $c$ in response to a one per cent increase in its price, by expenditure quartile. ${ }^{13}$ The results can be interpreted as follows: the own-price elasticity of food in the first quartile is -0.692. If the food price rises by one per cent, households in the first quartile reduce their food consumption by $0.692 \%$. All own-price elasticities are significantly different from zero, not least due to the high number of observations in our dataset. ${ }^{14}$

Three patterns can be observed in table 3. First, demand reacts elastically to price changes for only four consumption purposes: housing, leisure, health and education and others. The corresponding $O P E_{c}$ are below -1, implying that an increase in price leads to a more than proportional reduction in demand. While it is expected that households adjust their demand for leisure activities in response to price changes, they also exhibit surprisingly large reactions to housing prices. The $c$ "others encompasses various services,

\footnotetext{
${ }^{13}$ The estimated own-price elasticities by socio-demographic characteristics are available from the authors upon request.

${ }^{14}$ The estimated model parameters are shown in table 11 and 12 in appendix C.
} 


\begin{tabular}{lcccc}
\hline \hline \multicolumn{4}{c}{ Quartile } \\
& 1 & 2 & 3 & 4 \\
\hline Food & $-0.692^{* * *}$ & $-0.732^{* * *}$ & $-0.750^{* * *}$ & $-0.790^{* * *}$ \\
Housing & $-0.937^{* * *}$ & $-0.959^{* * *}$ & $-0.976^{* * *}$ & $-1.010^{* * *}$ \\
Energy & $-0.476^{* * *}$ & $-0.511^{* * *}$ & $-0.552^{* * *}$ & $-0.673^{* * *}$ \\
Transport & $-0.582^{* * *}$ & $-0.497^{* * *}$ & $-0.414^{* * *}$ & $-0.344^{* * *}$ \\
Communication & $-0.745^{* * *}$ & $-0.703^{* * *}$ & $-0.680^{* * *}$ & $-0.636^{* * *}$ \\
Leisure & $-0.842^{* * *}$ & $-0.917^{* * *}$ & $-0.968^{* * *}$ & $-1.041^{* * *}$ \\
Clothing & $-0.741^{* * *}$ & $-0.793^{* * *}$ & $-0.818^{* * *}$ & $-0.838^{* * *}$ \\
Health \& Edu & $-0.842^{* * *}$ & $-0.939^{* * *}$ & $-1.005^{* * *}$ & $-1.113^{* * *}$ \\
Appliances & $-0.286^{* * *}$ & $-0.488^{* * *}$ & $-0.620^{* * *}$ & $-0.795^{* * *}$ \\
Others & $-0.902^{* * *}$ & $-1.072^{* * *}$ & $-1.091^{* * *}$ & $-1.056^{* * *}$ \\
\hline \hline
\end{tabular}

Table 3

Own-price elasticities by consumption purpose and expenditure quartile Significance levels: ${ }^{*} p<0.10,{ }^{* *} p<0.05,{ }^{* * *} p<0.01$.

including financial and insurance services. Households reduce their demand for these services notably if prices increase.

Second, demand for energy and transport is the most inelastic across expenditure levels. With an own-price elasticity of -0.286 , demand for appliances by households in the first quartile is remarkably inelastic as well, plausibly reflecting demand for basic household appliances. These low own-price elasticities indicate that households find it challenging to substitute some consumption purposes and that price-based instruments are unlikely to substantially reduce their demand for them.

Third, own-price elasticities rise in expenditures for all consumption purposes except for transportation and communication. ${ }^{15}$ High-affluence households find it easier than low-affluence households to adapt to rising prices. This result cautions against regressive consumption-based taxes. Unresponsive to price signals, low-affluence households are more likely to pay higher prices for taxed goods rather then reducing demand. Regressive distributive effects are particularly likely for consumption purposes such as energy for which low-affluence households exhibit a high budget share and a low own-price elasticity.

Expenditure elasticities $\left(E E_{c}\right)$ by $c$ and expenditure quartile are displayed in table 4. The results are in line with those in figure 2: transportation, leisure, clothing, health and education, appliances, and other goods exhibit expenditure elasticities greater than unity. Commodities exhibiting an $E E_{c}$ greater than unity are defined as luxury goods, their budget shares grow in affluence. Taxing them may be progressive because high-affluence

\footnotetext{
${ }^{15}$ Generally, the own-price elasticities of the fourth and the other quartiles differ statistically significantly from each other.
} 
households bear the largest tax burden (see Creedy and Sleeman, 2006). Food, housing, energy, and communication are necessity goods. Exhibiting expenditure elasticities below unity, their budget shares fall when households' budgets rise.

\begin{tabular}{lcccc}
\hline \hline \multicolumn{4}{c}{ Quartile } \\
& 1 & 2 & 3 & 4 \\
\hline Food & $0.543^{* * *}$ & $0.689^{* * *}$ & $0.754^{* * *}$ & $0.756^{* * *}$ \\
Housing & $0.481^{* * *}$ & $0.540^{* * *}$ & $0.598^{* * *}$ & $0.555^{* * *}$ \\
Energy & $0.572^{* * *}$ & $0.628^{* * *}$ & $0.631^{* * *}$ & $0.519^{* * *}$ \\
Transport & $1.455^{* * *}$ & $1.457^{* * *}$ & $1.569^{* * *}$ & $1.775^{* * *}$ \\
Communication & $0.429^{* * *}$ & $0.329^{* * *}$ & $0.298^{* * *}$ & $0.385^{* * *}$ \\
Leisure & $1.764^{* * *}$ & $1.450^{* * *}$ & $1.253^{* * *}$ & $1.136^{* * *}$ \\
Clothing & $1.164^{* * *}$ & $1.071^{* * *}$ & $1.028^{* * *}$ & $0.987^{* * *}$ \\
Health \& Edu & $1.785^{* * *}$ & $1.565^{* * *}$ & $1.377^{* * *}$ & $1.255^{* * *}$ \\
Appliances & $1.731^{* * *}$ & $1.576^{* * *}$ & $1.471^{* * *}$ & $1.395^{* * *}$ \\
Others & $1.188^{* * *}$ & $1.086^{* * *}$ & $1.038^{* * *}$ & $1.173^{* * *}$ \\
\hline \hline
\end{tabular}

Table 4

Expenditure elasticities by consumption purpose and expenditure quartile Significance levels: ${ }^{*} p<0.10,{ }^{* *} p<0.05,{ }^{* * *} p<0.01$.

Expenditure elasticities evolve heterogeneously between the first and the fourth quartile. They increase monotonously for food and transport but fall for leisure, clothing, health and education, as well as appliances. Expenditure elasticities exhibit non-linear patterns for housing, energy, communication, and others. For many $c$, the differences in expenditure elasticities between the third and the fourth quartile are both statistically and economically significant. The $E E_{c}$ for energy, for instance, falls from 0.631 to 0.519 while the $E E_{c}$ for transport increases from 1.455 to 1.775 . The EASI, which models the relationship between budget and demand in a non-linear way, reveals that high-affluence households' consumption decisions are affected differently by budget changes than lowaffluence households'.

Our estimated $O P E_{c}$ and $E E_{c}$ for food, energy, and transportation resemble recent results by Nikodinoska and Schroeder (2016) for Germany. Our $O P E_{c}$ for leisure and clothing can be compared to the own-price elasticities found in Blundell and Robin (1999). Regarding $E E_{c}$ for appliances, leisure, and clothing, Salotti et al. (2015) provide estimates for different countries which are in line with ours.

\subsection{Material Footprints' Responses to Price and Budget Changes}

In this subsection, we convert the price and expenditure elasticities into changes in material footprints. Table 5 displays the changes in MF due to a one per cent increase in the price of a $c$, measured in million tons (Mt). Rising prices affect households' MF in two 
ways: first, the negative own-price elasticities indicate that households consume less of the $c$ whose price rises, reducing material footprints (own-price effect). Second, they adjust their demand for other consumption purposes, either increasing or decreasing MF. The latter effect is quantified by the cross-price elasticities $C P E_{c c, c}$ which record the change in demand for consumption purpose $c c$ in response to a one per cent price increase for consumption purpose $c$ (cross-price effect). ${ }^{16}$

The changes in MF are computed by multiplying $O P E_{c}$ and $C P E_{c c, c}$ with their respective material footprints and weighing them to consider the population composition regarding household expenditures and size. Results are displayed for the four expenditure quartiles as well as for all households. A value of -0.82 for food in the first quartile, for instance, implies that the material footprint of households in the first quartile falls by 820,000 tons in response to a one percent food price increase, considering both own and cross-price effects.

\begin{tabular}{lccccc}
\hline \hline & \multicolumn{5}{c}{ Quartile } \\
& 1 & 2 & 3 & 4 & Total \\
\hline Food & -0.82 & -0.81 & -0.81 & -0.83 & -3.27 \\
Housing & -0.57 & -0.59 & -0.61 & -0.72 & -2.48 \\
Energy & -0.28 & -0.26 & -0.27 & -0.32 & -1.13 \\
Transport & -0.28 & -0.43 & -0.54 & -1.51 & -2.76 \\
Communication & -0.03 & -0.02 & -0.02 & -0.02 & -0.10 \\
Leisure & -0.28 & -0.37 & -0.46 & -0.76 & -1.87 \\
Clothing & -0.08 & -0.12 & -0.16 & -0.26 & -0.63 \\
Health \& Edu & -0.36 & -0.45 & -0.51 & -0.73 & -2.05 \\
Appliances & -0.10 & -0.20 & -0.30 & -0.63 & -1.22 \\
Others & -0.04 & -0.06 & -0.08 & -0.12 & -0.30 \\
\hline \hline
\end{tabular}

Table 5

Total change in material footprint due to a one per cent price increase in $\mathrm{Mt}$

Rising food prices lead to the largest reduction in material footprints. If they increase by one per cent, German households' MF falls by 3.27 Mt. Price increases for transport (-2.76 Mt), housing (-2.49 Mt), and health and education (-2.05 Mt) lead to reductions in MF of more than two Mt as well. Clothing, others, and, in particular, communication are on the other end of the spectrum: a one per cent increase in prices for communication goods only reduces MF by $0.10 \mathrm{Mt}$.

Considering both own-price and cross-price effects leads to considerably larger MF reductions than only considering own-price effects. Exceptions are housing as well as health and education. If housing prices increase by one per cent, the MF of German

\footnotetext{
${ }^{16}$ The estimated cross price elasticities are available from the authors upon request.
} 
households falls by only $2.48 \mathrm{Mt}$, which is low considering that housing is material intensive and demand for it is price elastic. The own-price effect of housing, indeed, reduces MF by $2.46 \mathrm{Mt}$. But households re-allocate their expenditures to other material-intensive consumption purposes such as health and education, leisure, and appliances, leading to a negligible cross-price effect.

A one per cent increase in prices of leisure goods leads to a $1.87 \mathrm{Mt}$ reduction in material footprints. Decreasing their MF by $0.76 \mathrm{Mt}$, households in the fourth expenditure quartile account for $40.8 \%$ of this reduction. The households in the first quartile only reduce their material footprints by $0.28 \mathrm{Mt}$. Wealthy households spend a larger fraction of their budget on leisure activities and exhibit a higher price elasticity. Therefore, they account for the largest fraction of the reduction in MF. Similar patterns can be observed for appliances and transport where households in the fourth quartile account for $51.5 \%$ and $54.8 \%$ of the total reduction, respectively. The material footprint reductions due to increasing food prices are almost equally distributed: the first quartile accounts for $24.9 \%$ thereof, the fourth for $25.4 \%$.

Table 6 shows the change in MF in response to a one percent increase in expenditures. A value of 0.41 for food in the first quartile means that the material footprint due to food increases by $410,000 \mathrm{t}$ if the expenditure levels of households in that quartile rises by one per cent.

\begin{tabular}{lccccc}
\hline \hline & \multicolumn{5}{c}{ Quartile } \\
& 1 & 2 & 3 & 4 & Total \\
\hline Food & 0.41 & 0.49 & 0.57 & 0.63 & 2.10 \\
Housing & 0.28 & 0.32 & 0.38 & 0.50 & 1.48 \\
Energy & 0.22 & 0.24 & 0.26 & 0.27 & 0.99 \\
Transport & 0.32 & 0.46 & 0.61 & 1.73 & 3.12 \\
Communication & 0.02 & 0.01 & 0.01 & 0.02 & 0.06 \\
Leisure & 0.35 & 0.46 & 0.51 & 0.75 & 2.07 \\
Clothing & 0.13 & 0.16 & 0.18 & 0.26 & 0.73 \\
Health \& Edu & 0.52 & 0.59 & 0.60 & 0.83 & 2.54 \\
Appliances & 0.26 & 0.39 & 0.49 & 0.88 & 2.01 \\
Others & 0.05 & 0.07 & 0.08 & 0.12 & 0.32 \\
\hline \hline
\end{tabular}

Table 6

Changes in material footprint due to a one per cent expenditure increase in $\mathrm{Mt}$

A one per cent rise in budgets leads to an increase in material footprints due to transport of 3.12 Mt. Households in the fourth quartile alone account for 1.73 Mt. The MF due to food as well as health and education also rise by more than 2 Mt. Altogether, the material footprint of German households rises by $15.35 \mathrm{Mt}$ if expenditures increase by one per cent. 


\section{Policy Implications}

Material extraction often takes place in low-income countries which lack strong institutions able to implement and enforce environmental regulation at the the mine level (Congleton, 1992; Welsch, 2004). Therefore, first-best regulation of material extraction, which corrects material prices such that they reflect externalities due to environmental damages and force producers as well as consumers to adjust their behaviour accordingly, are not always feasible.

A large fraction of global material extraction is used to produce goods consumed in high-income countries (Wiedmann et al., 2015). Reducing the demand for materialintensive goods in these nations, consumption-based policies could serve as second-best instruments to limit material use. They are, however, subject to practical restrictions. On the one hand, regulating products according to their individual material footprints appears prohibitively costly because studies estimating the MF of each product sold in an economy would be necessary. On the other hand, a uniform increase of consumption taxes is unlikely to cause major reductions in MF. It leaves relative prices unchanged and the proportional relationship between expenditures and material footprints suggests that redistributing tax revenues to specific household groups has no major effects on material footprints either.

This study provides evidence on whether price increases for broadly defined consumption purposes, for instance due to consumption taxes, are effective instruments to reduce material use. It, furthermore, indicates which household groups are likely to be burdened by these increases. Its results suggest three distinct types of consumption purposes.

The first type encompasses consumption purposes for which price increases do not cause large reductions in MF, either because demand is inelastic (energy) or because households shift their demand to other material-intensive goods (housing). Non-price instruments can be expected to be more effective for reducing material footprint due to these consumption purposes.

The second type of consumption purposes exhibits material footprints which react elastically to rising prices. Low-affluence households would, however, be burdened disproportionally by these price rises. Households in the first expenditure quartile spend, for instance, around $20 \%$ of their budget on food and exhibit a low price elasticity for it. Instruments which increase prices for these consumption purposes should be accompanied by measures compensating low-affluence households.

The third type encompasses luxury consumption purposes such as leisure and private 
transport. Price increases for them imply fairly large reductions in material footprints and minor burdens on low-affluence households because budget shares for these consumption purposes rise in affluence. They are prime candidates for price-based instruments if policy makers are concerned with the distributive effects of their policies.

\section{Conclusions}

This paper investigates the within-country heterogeneity of material footprints (MF) in Germany combining data from the global multi-region input-output database Exiobase with an exact affine Stone index (EASI) demand system, estimated by using data from the German sample survey of income and expenditure (Einkommens- und Verbrauchsstichprobe, EVS). It is the first to reveal the distribution of material footprints among households in Germany as well as the first to show how these footprints react to price and expenditure changes.

Four conclusions can be drawn from our results. First, the within-country heterogeneity of material footprints in Germany is substantial and the its distribution is right-skewed. Households in the quartile with the highest expenditures exhibit, on average, a material footprint which is more than three times as large as that of households in the quartile with the lowest expenditures. Material footprints exceed $100 \mathrm{t}$ in almost one per cent of all households in Germany. Countries with a more unequal income distribution can be expected to exhibit even more heterogeneous material footprints, increasing the importance of studying households' material footprints rather than national aggregates.

Second, there is a close relationship between households' affluence and their material footprints. Our results indicate that material footprints increase almost in proportion to expenditure. If rich households, however, purchase more expensive goods than poor households and if higher prices are due to more labour rather than material inputs, the relationship between consumption expenditures and material footprints becomes non-linear. To allow researchers addressing this non-linearity directly, it is important that consumption surveys collect also physical measures of consumption to complement input-output data.

Third, the composition of consumption purposes responsible for the material footprints changes in growing expenditures. While food, housing, and energy account for a substantial share of rich and poor households' material footprints alike, transport, leisure, and appliances are particularly important for high-affluence households. The EASI demand system, which allows for a flexible relationship between budget and demand, reveals 
that consumption patterns change particularly between the third and the fourth quartile. Further research should investigate high-affluence households' consumption behaviour, providing additional insights on how to reduce their substantial material footprints.

Fourth, second-best policies aiming at discouraging material-intensive consumption should differentiate between consumption purposes. Price-based instruments can reduce the demand for luxury consumption purposes such as leisure and (private) transport without causing undesirable distributive effects. The material footprint due to energy does not react substantially to price signals, indicating that non-price policies are likely to be more effective. A possible extension for this study is to analyse policies to discourage material-intensive consumption patterns and assess their efficiency, their ecological as well as their distributive impacts, once proposals for such policies have been formulated. Permitting ex-ante policy simulations, the EASI demand system in combination with the material footprints as proposed here can be a valuable tool in this process 


\section{References}

Aguiar, A., Narayanan, B., and McDougall., R. (2016). An Overview of the GTAP 9 Data Base. Journal of Global Economic Analysis, 1(1):181-208.

Andrew, R. M. and Peters, G. P. (2013). A Multi-Region Input-Output Table Based on the Global Trade Analysis Project Database (GTAP-MRIO). Economic Systems Research, 25(1):99-121.

Arto, I., Genty, A., Rueda-Cantuche, J. M., Villanueva, A., and Andreoni, V. (2012). Global Resources Use and Pollution, Volume 1 / Production, Consumption and Trade (1995-2008). JRC Scientific and Technical Research Reports.

Bahn-Walkowiak, B. and Steger, S. (2015). Resource Targets in Europe and Worldwide: An Overview. Resources, 4(3):597-620.

Baiocchi, G., Minx, J., and Hubacek, K. (2010). The Impact of Social Factors and Consumer Behavior on Carbon Dioxide Emissions in the United Kingdom. Journal of Industrial Ecology, 14(1):50-72.

Baker, P., Blundell, R., and Micklewright, J. (1989). Modelling household energy expenditures using micro-data. The Economic Journal, 99(397):720-738.

Banks, J., Blundell, R., and Lewbel, A. (1997). Quadratic Engel Curves And Consumer Demand. The Review of Economics and Statistics, 79(4):527-539.

Binder, C. R., Graedel, T. E., and Reck, B. (2008). Explanatory Variables for per Capita Stocks and Flows of Copper and Zinc. Journal of Industrial Ecology, 10(1-2):111-132.

Blundell, R. and Robin, J. M. (1999). Estimation in large and disaggregated demand systems: an estimator for conditionally linear systems. Journal of Applied Econometrics, 14(3):209-232.

Brandt, A. R., Heath, G. A., Kort, E. A., O’Sullivan, F., Pétron, G., Jordaan, S. M., Tans, P., Wilcox, J., Gopstein, A. M., Arent, D., Wofsy, S., Brown, N. J., Bradley, R., Stucky, G. D., Eardley, D., and Harriss, R. (2014). Methane Leaks from North American Natural Gas Systems. Science, 343(6172):733 LP - 735.

Bruckner, M., Giljum, S., Lutz, C., and Wiebe, K. S. (2012). Materials Embodied in International Trade - Global Material Extraction and Consumption Between 1995 and 2005. Global Environmental Change, 22(3):568-576.

Bundesregierung (2002). Perspektiven für Deutschland. Unsere Strategie für eine nachhaltige Entwicklung.

Cederberg, C. and Mattsson, B. (2000). Life cycle assessment of milk production - a comparison of conventional and organic farming. Journal of Cleaner Production, 8(1):49-60.

Congleton, R. D. (1992). Political Institutions and Pollution Control. Review of Economics and Statistics, 74(3):412-421.

Creedy, J. and Sleeman, C. (2006). Carbon taxation, prices and welfare in New Zealand. Ecological Economics, 57(3):333-345.

Csavina, J., Field, J., Taylor, M. P., Gao, S., Landázuri, A., Betterton, E. A., and Sáez, A. E. (2012). A review on the importance of metals and metalloids in atmospheric dust and aerosol from mining operations. Science of The Total Environment, 433:58-73.

Daigo, I., Hashimoto, S., Matsuno, Y., and Adachi, Y. (2009). Material stocks and flows accounting for copper and copper-based alloys in Japan. Resources, Conservation and Recycling, 53(4):208-217. 
de Koning, A., Bruckner, M., Lutter, S., Wood, R., Stadler, K., and Tukker, A. (2015). Effect of aggregation and disaggregation on embodied material use of products in inputoutput analysis. Ecological Economics, 116:289-299.

Deaton, A. and Muellbauer, J. (1980). An Almost Ideal Demand System. American Economic Review, 70(3):312-326.

Dietzenbacher, E., Los, B., Stehrer, R., Timmer, M., and de Vries, G. (2013). The Construction of World Input-Output Tables in the WIOD Project. Economic Systems Research, 25(1):71-98.

Druckman, A. and Jackson, T. (2009). The carbon footprint of UK households 1990-2004: A socio-economically disaggregated, quasi-multi-regional input-output model. Ecological Economics, 68(7):2066-2077.

Dudka, S. and Adriano, D. C. (1997). Environmental Impacts of Metal Ore Mining and Processing: A Review. Journal of Environmental Quality, 26(3):590-602.

EU Commission (2011a). A Resource-Efficient Europe - Flagship Initiative of the Europe 2020 Strategy. COM(2011) 21.

EU Commission (2011b). Roadmap to a Resource Efficient Europe. COM(2011) 571 final. Brussels.

EU Commission (2014a). Report on Critical Raw Materials for the EU. Report of the Ad hoc Working Group on Defining Critical Raw Materials. May 2014.

EU Commission (2014b). Towards a circular economy: A zero waste programme for Europe. COM(2014) 398 final/2. Brussels.

Eurostat (2008). Eurostat Manual of Supply, Use and Input-Output Tables. Luxembourg.

Eurostat (2013). European System of Accounts 2010. Publications Office of the European Union, Luxembourg.

Fang, K. and Heijungs, R. (2014). Moving from the material footprint to a resource depletion footprint. Integrated environmental assessment and management, 10(4):5968 .

Giljum, S., Bruckner, M., and Martinez, A. (2015). Material Footprint Assessment in a Global Input-Output Framework. Journal of Industrial Ecology, 19(5):792-804.

Giljum, S., Wieland, H., Lutter, S., Bruckner, M., Wood, R., Tukker, A., and Stadler, K. (2016). Identifying priority areas for European resource policies: a MRIO-based material footprint assessment. Journal of Economic Structures, 5(1):17.

Girod, B. and De Haan, P. (2010). More or Better? A Model for Changes in Household Greenhouse Gas Emissions due to Higher Income. Journal of Industrial Ecology, 14(1):31-49.

Graedel, T. E., van Beers, D., Bertram, M., Fuse, K., Gordon, R. B., Gritsinin, A., Kapur, A., Klee, R. J., Lifset, R. J., Memon, L., Rechberger, H., Spatari, S., and Vexler, D. (2004). Multilevel Cycle of Anthropogenic Copper. Environmental Science \& Technology, 38(4):1242-1252.

Grösche, P. and Schroder, C. (2014). On the redistributive effects of germany's feed-in tariff. Empirical Economics, 46(4):1339-1383.

Guo, X. and Song, Y. (2008). Substance flow analysis of copper in China. Resources, Conservation and Recycling, 52(6):874-882. 
Harmsen, J., Roes, A., and Patel, M. (2013). The impact of copper scarcity on the efficiency of 2050 global renewable energy scenarios. Energy, 50:62-73.

Herendeen, R. (1978). Total energy cost of household consumption in Norway, 1973. Energy, 3(5):615-630.

Herendeen, R. and Tanaka, J. (1976). Energy cost of living. Energy, 1(2):165-178.

Hertwich, E. G. (2005). Life Cycle Approaches to Sustainable Consumption: A Critical Review. Environmental Science \&5 Technology, 39(13):4673-4684.

Hoekstra, A. Y. and Wiedmann, T. O. (2014). Humanity's Unsustainable Environmental Footprint. Science, 344(6188):1114-1117.

ICSG (2016). World Copper Factbook 2016.

Ivanova, D., Stadler, K., Steen-Olsen, K., Wood, R., Vita, G., Tukker, A., and Hertwich, E. G. (2015). Environmental Impact Assessment of Household Consumption. Journal of Industrial Ecology.

Kotakorpi, E., Lähteenoja, S., and Lettenmeier, M. (2008). Household MIPS. Natural resource consumption of Finnish households and its reduction. The Finnish Environment, $43 \mathrm{en}$.

Kovanda, J. and Weinzettel, J. (2013). The Importance of Raw Material Equivalents in Economy-Wide Material Flow Accounting and its Policy Dimension. Environmental Science ES Policy, 29:71-80.

Labandeira, X., Labeaga, J., and Rodriguez, M. (2006). A residential energy demand system for spain. The Energy Journal, Volume 27(Number 2):87-112.

Lenzen, M., Moran, D., Kanemoto, K., and Geschke, A. (2013). Building Eora: A Global Multi-Region Input-Output Database at High Country and Sector Resolution. Economic Systems Research, 25(1):20-49.

Lenzen, M., Wier, M., Cohen, C., Hayami, H., Pauchauri, S., and Schaeffer, R. (2006). A comparative multivariate analysis of household energy requirements in Australia, Brazil, Denmark, India and Japan. Energy, 31(2-3):181-207.

Lettenmeier, M., Laakso, S., Hirvilammi, T., Lähteenoja, S., and Aalto, K. (2012). Material Footprint of Low-income Households in Finland - is it Sustainable? Sustainability, $4: 1426-1447$.

Lewbel, A. (1989). Identification and Estimation of Equivalence Scales under Weak Separability. Review of Economic Studies, 56(2):311-316.

Lewbel, A. and Pendakur, K. (2009). Tricks with Hicks: The EASI Demand System. American Economic Review, 99(3):827-63.

Lutter, S., Giljum, S., and Bruckner, M. (2016). A review and comparative assessment of existing approaches to calculate material footprints. Ecological Economics, 127:1-10.

Miller, R. E. and Blair, P. D. (2009). Input-Output Analysis. Foundations and Extensions. Cambridge University Press, 2nd editio edition.

Muñoz, P., Giljum, S., and Roca, J. (2009). The Raw Material Equivalents of International Trade. Empirical Evidence for Latin America. Journal of Industrial Ecology, 13(6):881897.

Narayanan, G., Badri, A. A., and McDougall, R. (2012). Global Trade, Assistance, and Production: The GTAP 8 Data Base. Center for Global Trade Analysis, Purdue University. 
Nikodinoska, D. and Schroeder, C. (2016). On the emissions-inequality and emissionswelfare trade-offs in energy taxation: Evidence on the german car fuels tax. Resource and Energy Economics, 44:206 - 233.

Norgate, T. and Haque, N. (2010). Energy and greenhouse gas impacts of mining and mineral processing operations. Journal of Cleaner Production, 18(3):266-274.

Norgate, T., Jahanshahi, S., and Rankin, W. (2007). Assessing the environmental impact of metal production processes. Journal of Cleaner Production, 15(8):838-848.

Pashardes, P., Pashourtidou, N., and Zachariadis, T. (2014). Estimating welfare aspects of changes in energy prices from preference heterogeneity. Energy Economics, 42(C):5866 .

Pendakur, K. (2009). EASI made Easier. In Slottje, D., editor, Quantifying Consumer Preferences, chapter 7, pages 179-206. Emerald Group Publishing, London.

Piñero, P., Heikkinen, M., Mäenpää, I., and Pongrácz, E. (2015). Sector aggregation bias in environmentally extended input output modeling of raw material flows in Finland. Ecological Economics, 119:217-229.

Pothen, F. (2017). A structural decomposition of global Raw Material Consumption. Ecological Economics, 141:154-165.

Pothen, F. and Welsch, H. (2017). Economic Development and Material Use. Evidence from International Panel Data. Hannover Economic Papers, 588.

Rooney, R. C., Bayley, S. E., and Schindler, D. W. (2012). Oil sands mining and reclamation cause massive loss of peatland and stored carbon. Proceedings of the National Academy of Sciences of the United States of America, 109(13):4933-7.

Salotti, S., Montinari, L., Amores, A. F., and Rueda-Cantuche, J. M. (2015). Total expenditure elasticity of non-durable consumption of european households. JRC Technical Report EUR 27081.

Schaffartzik, A., Eisenmenger, N., Krausmann, F., and Weisz, H. (2014). Consumptionbased Material Flow Accounting. Austrian Trade and Consumption in Raw Material Equivalents 1995-2007. Journal of Industrial Ecology, 18(1):102-112.

Schoer, K., Weinzettel, J., Kovanda, J., Giegrich, J., and Lauwigi, C. (2012). Raw Material Consumption of the European Union - Concept, Calculation Method, and Results. Environmental Science \& Technology, 46(16):8903-8909.

Schoer, K., Wood, R., Arto, I., and Weinzettel, J. (2013). Estimating Raw Material Equivalents on a Macro-Level: Comparison of Multi-Regional Input-Output Analysis and Hybrid LCI-IO. Environmental Science \&3 Technology, 47(24):14282-14289.

Shigetomi, Y., Nansai, K., Kagawa, S., and Tohno, S. (2015). Trends in Japanese households' critical-metals material footprints. Ecological Economics, 119:118-126.

Shigetomi, Y., Nansai, K., Kagawa, S., and Tohno, S. (2016). Influence of income difference on carbon and material footprints for critical metals: the case of Japanese households. Journal of Economic Structures, 5(1).

Sommer, M. and Kratena, K. (2017). The Carbon Footprint of European Households and Income Distribution. Ecological Economics, 136:62-72.

Statistisches Bundesamt (2009). Volkswirtschaftliche Gesamtrechnungen. Input-OutputRechnung 2004. Fachserie 18 Reihe 2. Wiesbaden. 
Steen-Olsen, K., Wood, R., and Hertwich, E. G. (2016). The Carbon Footprint of Norwegian Household Consumption 1999-2012. Journal of Industrial Ecology, 20(3):582-592.

Timmer, M. P. (2012). The World Input-Output Database (WIOD): Contents, Sources and Methods. WIOD Working Paper, 10.

Timmer, M. P., Dietzenbacher, E., Los, B., Stehrer, R., and de Vries, G. J. (2015). An Illustrated User Guide to the World Input-Output Database: the Case of Global Automotive Production. Review of International Economics, 23(3):575-605.

Tovar Reaños, M. A. and Wölfing, N. M. (2018). Household energy prices and inequality: Evidence from German microdata based on the EASI demand system. Energy Economics, 70:84-97.

Tukker, A., de Koning, A., Wood, R., Hawkins, T., Lutter, S., Acosta, J., Rueda Cantuche, J. M., Bouwmeester, M., Oosterhaven, J., Drosdowski, T., and Kuenen, J. (2013). EXIOPOL-Development and Illustrative Analyses of a Detailed Global MR EE SUT/IOT. Economic Systems Research, 25(1):50-70.

U.S. Department of Energy (2011). Critical Materials Strategy.

van Beers, D. and Graedel, T. (2007). Spatial characterisation of multi-level in-use copper and zinc stocks in Australia. Journal of Cleaner Production, 15(8):849-861.

Weber, C. L. and Matthews, H. S. (2008). Quantifying the Global and Distributional Aspects of American Household Carbon Footprint. Ecological Economics, 66(2-3):379391.

Welsch, H. (2004). Corruption, Growth, and the Environment: A Cross-country Analysis. Environment and Development Economics, 9:663-693.

Wenzlik, M., Eisenmenger, N., and Schaffartzik, A. (2015). What Drives Austrian Raw Material Consumption? A Structural Decomposition Analysis for the Years 1995 to 2007. Journal of Industrial Ecology, 19(5):814-824.

Wiebe, K. S., Bruckner, M., Giljum, S., Lutz, C., and Polzin, C. (2012). Carbon and Materials Embodied in the International Trade of Emerging Economies. Journal of Industrial Ecology, 16(4):636-646.

Wiedmann, T. O., Schandl, H., Lenzen, M., Moran, D., Suh, S., West, J., and Kanemoto, K. (2015). The Material Footprint of Nations. Proceedings of the National Academy of Sciences, 112(20):6271-6276.

Wiedmann, T. O., Schandl, H., and Moran, D. (2014). The Footprint of Using Metals: New Metrics of Consumption and Productivity. Environmental Economics and Policy Studies.

Wier, M., Lenzen, M., Munksgaard, J., and Smed, S. (2001). Effects of Household Consumption Patterns on CO2 Requirements. Economic Systems Research, 13(3):259-274.

Wood, R., Stadler, K., Bulavskaya, T., Lutter, S., Giljum, S., de Koning, A., Kuenen, J., Schütz, H., Acosta-Fernández, J., Usubiaga, A., Simas, M., Ivanova, O., Weinzettel, J., Schmidt, J., Merciai, S., and Tukker, A. (2014). Global Sustainability Accounting Developing EXIOBASE for Multi-Regional Footprint Analysis. Sustainability, 7(1):138163. 


\section{A Adjusting the Matrix of Material Footprints}

\section{A.1 Basic Adjustments}

Let vector $\mathbf{f}_{\mathbf{h}}$ record household $h$ 's consumption expenditures as classified by the EVS. Each element $f_{c, h}$ corresponds to household $h$ 's expenditures on consumption purposes $c$ in purchasers' prices. First, the material footprints are converted from basic to purchasers' prices. $\mathbf{M} \mathbf{F}$ is corrected for the net taxes on consumption which households pay. Furthermore, it is corrected for trade margins. Data on net taxes and trade margins are recorded in the Exiobase's valuation matrices. ${ }^{17}$

Second, we aggregate final consumption from different regions $r$ in the matrix of material footprints $(\overline{\mathbf{M}} \mathbf{F})$. Thereby, we implicitly assume that all households purchase goods from the same countries. This assumption has been made because there is no data in the EVS able to reveal whether different household types are more likely to consume domestic or imported goods.

Third, the products in the Exiobase's classification are aggregated into three-digit CPA (Classification of Products by Activity) products. This aggregation is necessary to relate products to commodities in the next step. It is conducted after estimating the per-euro material footprints $\overline{\mathbf{M}} \mathbf{F}$ to avoid introducing an aggregation bias (de Koning et al., 2015; Piñero et al., 2015).

Fourth, a matrix $\boldsymbol{K}$ relates products to consumption purposes. Each element $\kappa_{j, c}$ records the share of product $j$ in consumption purpose $c$, e.g. the share of refined petroleum products in the consumption purpose operation of personal transport equipment. The values for $\boldsymbol{K}$ are based on the consumption interdependence table (Konsumverflechtungstabelle) published by the German Statistical Office (Statistisches Bundesamt, 2009). It distinguishes between 41 three-digit COICOP expenditure categories and 71 CPA products. We use the last publicly available consumption interdependence table, which has been published for 2004, and disaggregate the COICOP category 045 (electricity, gas and other fuels) into electricity and heating to allow for a precise allocation of (material-intensive) fossil fuels. The details of this process are presented in section A.2 of the appendix A.

Fifth, we adjust the material footprints to account for materials embedded in residential dwellings (see section A.3 for details). Unlike other durable goods such as cars or appliances, the utilization of materials embedded in residential dwellings are neglected if

\footnotetext{
${ }^{17}$ We thank Richard Wood for providing them to us.
} 
material footprints are estimated according to equation (1) because the use of the building stock is not represented in the Leontief inverse $\mathbf{L}$.

\section{A.2 Preparing the Consumption Interdependence Table}

The COICOP expenditure category 045 in the consumption interdependence table can be disaggregated into the four-digit categories electricity (0451), gas (0452), liquid fuels (0453), solid fuels (0454), and heat energy (0455) under reasonable assumptions.

The inputs of CPA 2 (products of forestry, logging and related services) and CPA 10 (coal and lignite; peat) into COICOP 045 are allocated to COICOP 0454 (solid fuels). About $0.08 \%$ of the households' expenditure on electricity and fuels stems from CPA 24 (chemicals, chemical products and man-made fibers). We also allocate these products to the solid fuels category.

We allocate the households' consumption for product 11 (crude petroleum and natural gas; services incidental to oil and gas extraction, excluding surveying) to gas (COICOP 0452). German households do not consume crude oil which renders this assumption innocuous.

The product CPA 23 (coke, refined petroleum products. nuclear fuel) has to be disaggregated into CPA 231 (coke oven products) and CPA 232,233 (refined petroleum products, nuclear fuel). According to Exiobase data, about $4.4 \%$ of the final consumption of CPA 23 is coke. We assume that this share was the same in 2004. It is assumed that households' final consumption of coke is entirely used as a solid fuel. We, furthermore, assume that COICOP 72 (operation of personal transport equipment) only uses refined petroleum. The remaining consumption of CPA 232,233 is allocated to liquid fuels (COICOP 0453).

The product CPA 401,403 has to be disaggregated into CPA 401 (production and distribution services of electricity) and CPA 403 (steam and hot water supply services). According to the Exiobase, about $2.2 \%$ of the final consumption of CPA 401,403 is steam and hot water supply. We assume that this share was the same in 2004 and split CPA 401,403 accordingly. The corresponding final demand was allocated to COICOP 0455, the remainder to COICOP 0451.

\section{A.3 Materials Embedded in Residential Dwellings}

Computing the per-euro material footprint according to equations (1) underestimates the use of materials which are embedded in residential dwellings. The construction of new 
buildings is recorded as gross fixed capital formation (Eurostat, 2013, pp. 73). Rents paid by tenants and imputed rents for owner-occupied dwellings are allocated to the real estate services (CPA 70). Imputed rents are defined as the rent which a tenant would pay for the owner-occupied dwelling (Eurostat, 2013, pp. 66). The utilization of building stocks is not recorded as an intermediate input but as value added, more precisely as consumption of fixed capital (Eurostat, 2013, pp. 68). Thus, it is not accounted for in the Leontief inverse $\mathbf{L}$.

The consumption of fixed capital is defined as follows: "Consumption of fixed capital represents the amount of fixed assets used up during the period under consideration" (Eurostat, 2008, p.159). It can be interpreted as physical depreciation of the building stock. Consumption of fixed capital accounts for $27.9 \%$ of all inputs in German real estate services. We assume that it solely represents the physical depreciation of the building stock. Furthermore, we assume that the buildings have been constructed with the per-euro material footprint of today's German construction sector. Accounting for the materials embedded in residential dwelling raises the material footprint of real estate services in Germany by $232 \%$ and German households' material footprint by $9.8 \%$.

\section{B The Material Footprint of Copper}

The results in this study are presented for materials aggregated according to their physical mass. Studying an individual material allows to consider its particularities and provides a closer connection between material use and ecological impacts. In this section, we present results for the material footprint for copper, or copper footprint, as an example.

Copper $(\mathrm{Cu})$ is the 29th element in the periodic system. Due to its high electrical conductivity, copper is used in many electrical and electronic appliances. It is also used in construction, transportation equipment, and industrial machinery. The mine production of copper was 5.76 million tons in 2015. Almost one third thereof was extracted in Chile. Other major copper producers include China, Peru, the United States, and Australia (ICSG, 2016).

Despite being an essential trace element in human diet, copper is mildly toxic in high concentrations. Extracting and processing copper is associated with a number of environmental issues including waste generation and acidification (Norgate et al., 2007) as well as greenhouse gas emissions (Norgate and Haque, 2010).

The literature which studies the use of copper is too comprehensive to be fully reviewed here. Copper stocks and flows have been analyzed both on a global (Graedel et al., 2004) 
and on a country level (van Beers and Graedel, 2007; Daigo et al., 2009; Guo and Song, 2008). Binder et al. (2008) estimate the drivers of copper use, revealing a strong connection with GDP per capita. Harmsen et al. (2013) investigate the relationship between copper use and the deployment of renewable electricity generation up until 2050. To our knowledge, there is no study on the within-country heterogeneity of copper footprints.

Figure 4 displays the distribution of copper footprints among German households. On average, they exhibit a copper footprint of $742 \mathrm{~kg}$. The standard deviation equals 712 $\mathrm{kg}$. With a skewness of 5.99, the distribution of copper footprints is considerably more right-skewed than the distribution of material footprints which exhibits a skewness of 3.63 (figure 1). This suggests that high-impact households are more important for Germany's copper footprint than for its material footprint.

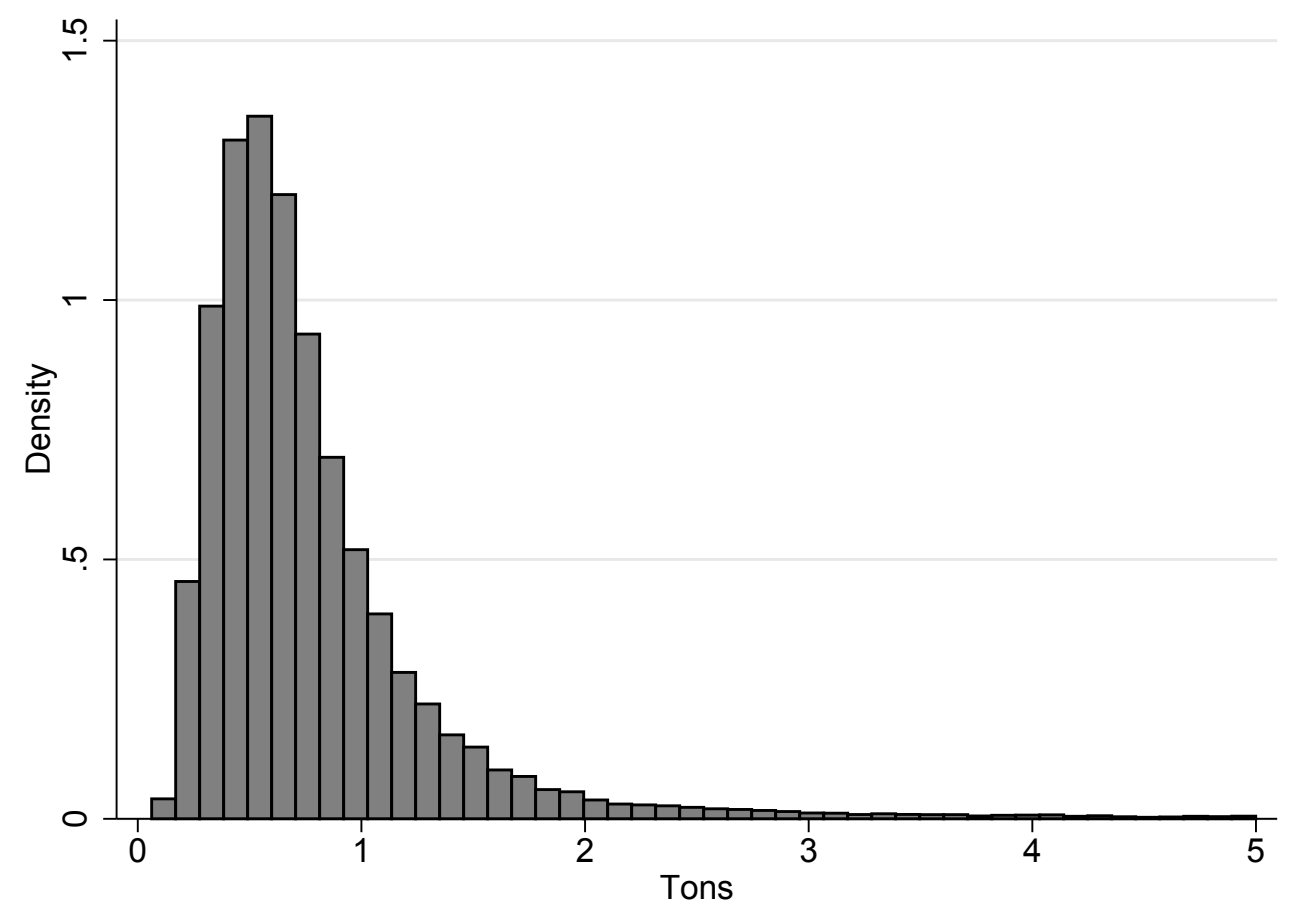

Figure 4

Distribution of households' copper footprints in Germany

Displaying households' copper footprint in tons by $c$ and expenditure quartile, figure 5 reveals which consumption patterns are responsible for the right-skewed distribution of copper footprints. It shows that all consumption purposes exhibit positive copper footprints because they all necessitate copper inputs at some point of the supply chain. Figure 5 shows notable increases of copper footprints for consumption purposes such as leisure and appliances. The increase due to transport is particularly striking. It quintuples between the third and the fourth quartile, from around $44 \mathrm{~kg}$ to 500kg. High-affluence households' purchases of cars are, thus, a prime contributor to Germany's copper footprint. 


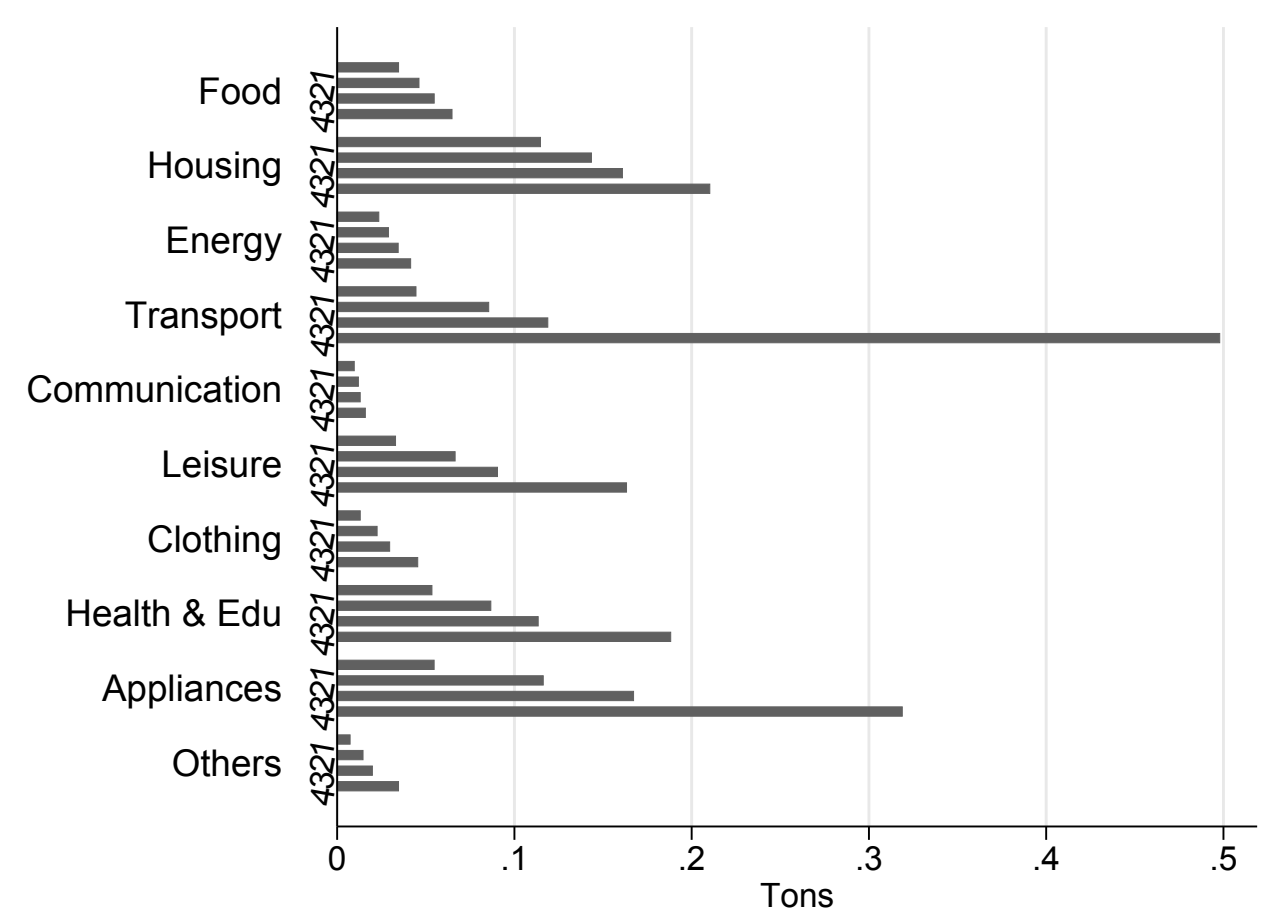

Figure 5

Copper footprints due to consumption purposes by expenditure quartile in $\mathrm{t}$

Average material footprint due to each consumption purpose for equivalised households. The numbers indicate the expenditure quartile.

Table 7 displays the total change in copper footprints in 1000 tons (kt) in response to a one per cent increase in price by expenditure quartile. Rising prices lead to the largest decreases in copper footprints for transport (-110.60 kt), housing (-79.78) as well as appliances $(-71.32 \mathrm{kt})$. The effect of a one per cent price increase for transport is mostly due to households in the fourth quartile reducing their copper footprint. Their copper footprint declines by 71,900 tons. The reduction of copper footprints due to appliances and leisure can also be ascribed to households in the fourth quartile. These results indicate that targeting high affluence households' demand for cars, leisure, and appliances might reduce Germany's copper footprint more effectively than its overall material footprint. 


\begin{tabular}{lccccc}
\hline \hline & \multicolumn{5}{c}{ Quartile } \\
& 1 & 2 & 3 & 4 & Total \\
\hline Food & -7.28 & -7.19 & -7.31 & -7.51 & -29.30 \\
Housing & -18.81 & -19.22 & -19.46 & -22.29 & -79.78 \\
Energy & -2.98 & -2.78 & -2.96 & -3.51 & -12.24 \\
Transport & -8.34 & -13.24 & -17.11 & -71.90 & -110.60 \\
Communication & -1.37 & -1.25 & -1.17 & -1.31 & -5.09 \\
Leisure & -6.72 & -9.56 & -11.67 & -20.65 & -48.61 \\
Clothing & -1.71 & -2.64 & -3.47 & -5.57 & -13.40 \\
Health \& Edu & -10.24 & -13.22 & -15.20 & -22.44 & -61.10 \\
Appliances & -5.74 & -11.80 & -17.70 & -36.08 & -71.32 \\
Others & -1.30 & -1.99 & -2.50 & -3.84 & -9.62 \\
\hline \hline
\end{tabular}

Table 7

Change in copper footprints due to a one per cent price increase in $\mathrm{kt}$

\section{Descriptive Statistics and Parameter Estimates}

\begin{tabular}{lcccc}
\hline \hline Quartile & 1 & 2 & 3 & 4 \\
\hline All households & 14.23 & 21.65 & 27.17 & 45.12 \\
Single retired & 15.20 & 27.48 & 39.79 & 70.33 \\
Single no children & 14.74 & 27.76 & 39.99 & 74.43 \\
Single with children & 11.96 & 17.92 & 25.41 & 48.33 \\
2 adults head retired & 13.14 & 19.97 & 28.61 & 50.40 \\
2 adults no children & 12.95 & 20.42 & 28.88 & 51.77 \\
2 adults one child & 11.37 & 17.05 & 23.93 & 39.93 \\
2 adults two children & 10.08 & 14.38 & 20.28 & 33.23 \\
Other households & 12.19 & 17.67 & 23.44 & 39.53 \\
\hline \hline
\end{tabular}

Table 8

Consumption expenditure by household group in 1,000 Euro 
Table 9

Summary statistics

\begin{tabular}{|c|c|c|}
\hline Variable & Mean & Std. Dev. \\
\hline \multicolumn{3}{|l|}{ Budget shares } \\
\hline Food & 0.15 & 0.06 \\
\hline Housing & 0.25 & 0.09 \\
\hline Energy & 0.05 & 0.03 \\
\hline Transport & 0.11 & 0.09 \\
\hline Communication & 0.03 & 0.02 \\
\hline Leisure & 0.16 & 0.09 \\
\hline Clothing & 0.05 & 0.03 \\
\hline Health \& Edu & 0.08 & 0.07 \\
\hline Appliances & 0.05 & 0.06 \\
\hline Others & 0.06 & 0.05 \\
\hline \multicolumn{3}{|l|}{ Log prices } \\
\hline Food & 4.40 & 0.25 \\
\hline Housing & 3.19 & 1.55 \\
\hline Energy & 3.64 & 0.42 \\
\hline Transport & 3.66 & 0.43 \\
\hline Communication & 4.63 & 0.29 \\
\hline Leisure & 3.91 & 0.34 \\
\hline Clothing & 4.41 & 0.24 \\
\hline Health \& Edu & 3.88 & 0.33 \\
\hline Appliances & 3.96 & 0.35 \\
\hline Others & 4.04 & 0.32 \\
\hline \multicolumn{3}{|l|}{ Other variables } \\
\hline Total expenditure & 9,459 & $4,992.9$ \\
\hline Central heating (CH) & 0.78 & 0.42 \\
\hline District heating (DH) & 0.14 & 0.35 \\
\hline Building date 1948 & 0.16 & 0.36 \\
\hline Building date 1949 - 1990 & 0.45 & 0.45 \\
\hline Dwelling size & 104.18 & 41.83 \\
\hline Below 20k inhabitants & 0.16 & 0.37 \\
\hline 20k-10k inhabitants & 0.26 & 0.44 \\
\hline $\mathrm{N}$ & \multicolumn{2}{|c|}{122,500} \\
\hline
\end{tabular}

Table 10

Frequencies of household types

\begin{tabular}{lcc}
\hline \hline & & \\
Type & absolute & relative \\
\hline Other households & 18,172 & 14.83 \\
Single +65, no children & 7,209 & 5.88 \\
Single, no children & 15,405 & 12.58 \\
Single, children & 13,541 & 11.05 \\
2 adults +65, no children & 5,565 & 4.54 \\
2 adults, no children & 31,191 & 25.46 \\
2 adults, one child & 16,237 & 13.25 \\
2 adults, two children & 15,180 & 12.39 \\
Total & 122,500 & 100.00 \\
\hline
\end{tabular}


Table 11

Iterated 3SLS used to estimate equation 5

\begin{tabular}{|c|c|c|c|c|c|c|c|c|c|}
\hline & $\begin{array}{l}w_{1} \\
\mathrm{~b} / \mathrm{se}\end{array}$ & $\begin{array}{l}w_{2} \\
\mathrm{~b} / \mathrm{se}\end{array}$ & $\begin{array}{l}w_{3} \\
\mathrm{~b} / \mathrm{se}\end{array}$ & $\begin{array}{l}w_{4} \\
\mathrm{~b} / \mathrm{se}\end{array}$ & $\begin{array}{l}w_{5} \\
\mathrm{~b} / \mathrm{se}\end{array}$ & $\begin{array}{l}w_{6} \\
\mathrm{~b} / \mathrm{se}\end{array}$ & $\begin{array}{l}w_{7} \\
\mathrm{~b} / \mathrm{se}\end{array}$ & $\begin{array}{l}w_{8} \\
\mathrm{~b} / \mathrm{se}\end{array}$ & $\begin{array}{l}w_{9} \\
\mathrm{~b} / \mathrm{se}\end{array}$ \\
\hline $\log (y)^{1}$ & $\begin{array}{l}3.264 \\
(0.402)\end{array}$ & $\begin{array}{l}12.752 \\
(0.553)\end{array}$ & $\begin{array}{l}0.288 \\
(0.239)\end{array}$ & $\begin{array}{l}3.830 \\
(0.653)\end{array}$ & $\begin{array}{c}-0.087 \\
(0.131)\end{array}$ & $\begin{array}{c}-10.604 \\
(0.692)\end{array}$ & $\begin{array}{c}-0.413 \\
(0.275)\end{array}$ & $\begin{array}{l}-7.366 \\
(0.520)\end{array}$ & $\begin{array}{c}-1.176 \\
(0.473)\end{array}$ \\
\hline $\log (y)^{2}$ & $\begin{array}{l}-1.014 \\
(0.118)\end{array}$ & $\begin{array}{c}-4.011 \\
(0.161)\end{array}$ & $\begin{array}{l}-0.127 \\
(0.070)\end{array}$ & $\begin{array}{l}-1.057 \\
(0.191)\end{array}$ & $\begin{array}{l}0.034 \\
(0.038)\end{array}$ & $\begin{array}{l}3.271 \\
(0.202)\end{array}$ & $\begin{array}{l}0.146 \\
(0.080)\end{array}$ & $\begin{array}{l}2.222 \\
(0.152)\end{array}$ & $\begin{array}{l}0.365 \\
(0.138)\end{array}$ \\
\hline $\log (y)^{3}$ & $\begin{array}{l}0.137 \\
(0.015)\end{array}$ & $\begin{array}{l}0.547 \\
(0.021)\end{array}$ & $\begin{array}{l}0.021 \\
(0.009)\end{array}$ & $\begin{array}{l}0.128 \\
(0.025)\end{array}$ & $\begin{array}{l}-0.006 \\
(0.005)\end{array}$ & $\begin{array}{c}-0.439 \\
(0.026)\end{array}$ & $\begin{array}{l}-0.021 \\
(0.010)\end{array}$ & $\begin{array}{l}-0.294 \\
(0.020)\end{array}$ & $\begin{array}{l}-0.049 \\
(0.018)\end{array}$ \\
\hline $\log (y)^{4}$ & $\begin{array}{l}-0.007 \\
(0.001)\end{array}$ & $\begin{array}{l}-0.028 \\
(0.001)\end{array}$ & $\begin{array}{l}-0.001 \\
(0.000)\end{array}$ & $\begin{array}{l}-0.006 \\
(0.001)\end{array}$ & $\begin{array}{l}0.000 \\
(0.000)\end{array}$ & $\begin{array}{l}0.022 \\
(0.001)\end{array}$ & $\begin{array}{l}0.001 \\
(0.000)\end{array}$ & $\begin{array}{l}0.014 \\
(0.001)\end{array}$ & $\begin{array}{l}0.002 \\
(0.001)\end{array}$ \\
\hline $\log (p 1)$ & $\begin{array}{l}0.135 \\
(0.007)\end{array}$ & $\begin{array}{l}-0.048 \\
(0.002)\end{array}$ & $\begin{array}{l}-0.009 \\
(0.003)\end{array}$ & $\begin{array}{l}0.001 \\
(0.004)\end{array}$ & $\begin{array}{l}0.012 \\
(0.002)\end{array}$ & $\begin{array}{l}-0.005 \\
(0.005)\end{array}$ & $\begin{array}{l}-0.011 \\
(0.004)\end{array}$ & $\begin{array}{l}-0.025 \\
(0.004)\end{array}$ & $\begin{array}{l}-0.038 \\
(0.004)\end{array}$ \\
\hline $\log (p 2)$ & $\begin{array}{l}-0.048 \\
(0.002)\end{array}$ & $\begin{array}{l}0.089 \\
(0.003)\end{array}$ & $\begin{array}{l}-0.018 \\
(0.001)\end{array}$ & $\begin{array}{l}0.034 \\
(0.003)\end{array}$ & $\begin{array}{l}-0.015 \\
(0.001)\end{array}$ & $\begin{array}{l}-0.064 \\
(0.003)\end{array}$ & $\begin{array}{l}-0.025 \\
(0.001)\end{array}$ & $\begin{array}{l}0.037 \\
(0.002)\end{array}$ & $\begin{array}{l}-0.021 \\
(0.002)\end{array}$ \\
\hline $\log (p 3)$ & $\begin{array}{l}-0.009 \\
(0.003)\end{array}$ & $\begin{array}{l}-0.018 \\
(0.001)\end{array}$ & $\begin{array}{l}0.114 \\
(0.003)\end{array}$ & $\begin{array}{l}-0.035 \\
(0.002)\end{array}$ & $\begin{array}{l}0.001 \\
(0.001)\end{array}$ & $\begin{array}{l}-0.010 \\
(0.003)\end{array}$ & $\begin{array}{l}0.002 \\
(0.002)\end{array}$ & $\begin{array}{l}-0.026 \\
(0.003)\end{array}$ & $\begin{array}{l}-0.006 \\
(0.002)\end{array}$ \\
\hline $\log (p 4)$ & $\begin{array}{l}0.001 \\
(0.004)\end{array}$ & $\begin{array}{l}0.034 \\
(0.003)\end{array}$ & $\begin{array}{l}-0.035 \\
(0.002)\end{array}$ & $\begin{array}{l}-0.064 \\
(0.007)\end{array}$ & $\begin{array}{l}0.005 \\
(0.001)\end{array}$ & $\begin{array}{l}-0.004 \\
(0.006)\end{array}$ & $\begin{array}{l}0.008 \\
(0.003)\end{array}$ & $\begin{array}{l}0.007 \\
(0.005)\end{array}$ & $\begin{array}{l}0.004 \\
(0.004)\end{array}$ \\
\hline $\log (p 5)$ & $\begin{array}{l}0.012 \\
(0.002)\end{array}$ & $\begin{array}{l}-0.015 \\
(0.001)\end{array}$ & $\begin{array}{l}0.001 \\
(0.001)\end{array}$ & $\begin{array}{l}0.005 \\
(0.001)\end{array}$ & $\begin{array}{l}0.008 \\
(0.002)\end{array}$ & $\begin{array}{l}0.006 \\
(0.002)\end{array}$ & $\begin{array}{c}-0.002 \\
(0.002)\end{array}$ & $\begin{array}{l}-0.006 \\
(0.002)\end{array}$ & $\begin{array}{l}-0.006 \\
(0.001)\end{array}$ \\
\hline $\log (p 6)$ & $\begin{array}{l}-0.005 \\
(0.005)\end{array}$ & $\begin{array}{l}-0.064 \\
(0.003)\end{array}$ & $\begin{array}{l}-0.010 \\
(0.003)\end{array}$ & $\begin{array}{l}-0.004 \\
(0.006)\end{array}$ & $\begin{array}{l}0.006 \\
(0.002)\end{array}$ & $\begin{array}{l}0.145 \\
(0.009)\end{array}$ & $\begin{array}{l}0.011 \\
(0.003)\end{array}$ & $\begin{array}{l}-0.054 \\
(0.005)\end{array}$ & $\begin{array}{l}-0.019 \\
(0.005)\end{array}$ \\
\hline $\log (p 7)$ & $\begin{array}{l}-0.011 \\
(0.004)\end{array}$ & $\begin{array}{l}-0.025 \\
(0.001)\end{array}$ & $\begin{array}{l}0.002 \\
(0.002)\end{array}$ & $\begin{array}{l}0.008 \\
(0.003)\end{array}$ & $\begin{array}{l}-0.002 \\
(0.002)\end{array}$ & $\begin{array}{l}0.011 \\
(0.003)\end{array}$ & $\begin{array}{l}0.008 \\
(0.004)\end{array}$ & $\begin{array}{l}-0.006 \\
(0.003)\end{array}$ & $\begin{array}{l}0.005 \\
(0.003)\end{array}$ \\
\hline $\log (p 8)$ & $\begin{array}{l}-0.025 \\
(0.004)\end{array}$ & $\begin{array}{l}0.037 \\
(0.002)\end{array}$ & $\begin{array}{l}-0.026 \\
(0.003)\end{array}$ & $\begin{array}{l}0.007 \\
(0.005)\end{array}$ & $\begin{array}{l}-0.006 \\
(0.002)\end{array}$ & $\begin{array}{l}-0.054 \\
(0.005)\end{array}$ & $\begin{array}{l}-0.006 \\
(0.003)\end{array}$ & $\begin{array}{l}0.107 \\
(0.007)\end{array}$ & $\begin{array}{l}-0.017 \\
(0.004)\end{array}$ \\
\hline $\log (p 9)$ & $\begin{array}{l}-0.038 \\
(0.004)\end{array}$ & $\begin{array}{l}-0.021 \\
(0.002)\end{array}$ & $\begin{array}{l}-0.006 \\
(0.002)\end{array}$ & $\begin{array}{l}0.004 \\
(0.004)\end{array}$ & $\begin{array}{l}-0.006 \\
(0.001)\end{array}$ & $\begin{array}{l}-0.019 \\
(0.005)\end{array}$ & $\begin{array}{l}0.005 \\
(0.003)\end{array}$ & $\begin{array}{l}-0.017 \\
(0.004)\end{array}$ & $\begin{array}{l}0.101 \\
(0.005)\end{array}$ \\
\hline $\log (p 1) \log (y)$ & $\begin{array}{l}-0.019 \\
(0.001)\end{array}$ & $\begin{array}{l}0.008 \\
(0.000)\end{array}$ & $\begin{array}{l}0.001 \\
(0.001)\end{array}$ & $\begin{array}{l}-0.003 \\
(0.001)\end{array}$ & $\begin{array}{l}-0.001 \\
(0.000)\end{array}$ & $\begin{array}{l}-0.001 \\
(0.001)\end{array}$ & $\begin{array}{l}0.001 \\
(0.001)\end{array}$ & $\begin{array}{l}0.006 \\
(0.001)\end{array}$ & $\begin{array}{l}0.006 \\
(0.001)\end{array}$ \\
\hline $\log (p 2) \log (y)$ & $\begin{array}{l}0.008 \\
(0.000)\end{array}$ & $\begin{array}{l}-0.016 \\
(0.000)\end{array}$ & $\begin{array}{l}0.003 \\
(0.000)\end{array}$ & $\begin{array}{l}-0.011 \\
(0.000)\end{array}$ & $\begin{array}{l}0.003 \\
(0.000)\end{array}$ & $\begin{array}{l}0.015 \\
(0.001)\end{array}$ & $\begin{array}{l}0.006 \\
(0.000)\end{array}$ & $\begin{array}{l}-0.007 \\
(0.000)\end{array}$ & $\begin{array}{l}0.005 \\
(0.000)\end{array}$ \\
\hline $\log (p 3) \log (y)$ & $\begin{array}{l}0.001 \\
(0.001)\end{array}$ & $\begin{array}{l}0.003 \\
(0.000)\end{array}$ & $\begin{array}{l}-0.017 \\
(0.000)\end{array}$ & $\begin{array}{l}0.005 \\
(0.000)\end{array}$ & $\begin{array}{l}-0.000 \\
(0.000)\end{array}$ & $\begin{array}{l}0.001 \\
(0.000)\end{array}$ & $\begin{array}{l}-0.001 \\
(0.000)\end{array}$ & $\begin{array}{l}0.005 \\
(0.000)\end{array}$ & $\begin{array}{l}0.001 \\
(0.000)\end{array}$ \\
\hline $\log (p 4) \log (y)$ & $\begin{array}{l}-0.003 \\
(0.001)\end{array}$ & $\begin{array}{l}-0.011 \\
(0.000)\end{array}$ & $\begin{array}{l}0.005 \\
(0.000)\end{array}$ & $\begin{array}{l}0.024 \\
(0.001)\end{array}$ & $\begin{array}{l}-0.001 \\
(0.000)\end{array}$ & $\begin{array}{l}0.001 \\
(0.001)\end{array}$ & $\begin{array}{c}-0.002 \\
(0.000)\end{array}$ & $\begin{array}{c}-0.002 \\
(0.001)\end{array}$ & $\begin{array}{c}-0.002 \\
(0.001)\end{array}$ \\
\hline $\log (p 5) \log (y)$ & $\begin{array}{c}-0.001 \\
(0.000)\end{array}$ & $\begin{array}{l}0.003 \\
(0.000)\end{array}$ & $\begin{array}{l}-0.000 \\
(0.000)\end{array}$ & $\begin{array}{l}-0.001 \\
(0.000)\end{array}$ & $\begin{array}{l}-0.000 \\
(0.000)\end{array}$ & $\begin{array}{c}-0.001 \\
(0.000)\end{array}$ & $\begin{array}{c}-0.001 \\
(0.000)\end{array}$ & $\begin{array}{l}0.001 \\
(0.000)\end{array}$ & $\begin{array}{l}0.000 \\
(0.000)\end{array}$ \\
\hline $\log (p 6) \log (y)$ & $\begin{array}{l}-0.001 \\
(0.001)\end{array}$ & $\begin{array}{l}0.015 \\
(0.001)\end{array}$ & $\begin{array}{l}0.001 \\
(0.000)\end{array}$ & $\begin{array}{l}0.001 \\
(0.001)\end{array}$ & $\begin{array}{l}-0.001 \\
(0.000)\end{array}$ & $\begin{array}{l}-0.027 \\
(0.002)\end{array}$ & $\begin{array}{l}-0.002 \\
(0.001)\end{array}$ & $\begin{array}{l}0.010 \\
(0.001)\end{array}$ & $\begin{array}{l}0.003 \\
(0.001)\end{array}$ \\
\hline $\log (p 7) \log (y)$ & $\begin{array}{l}0.001 \\
(0.001)\end{array}$ & $\begin{array}{l}0.006 \\
(0.000)\end{array}$ & $\begin{array}{l}-0.001 \\
(0.000)\end{array}$ & $\begin{array}{l}-0.002 \\
(0.000)\end{array}$ & $\begin{array}{l}-0.001 \\
(0.000)\end{array}$ & $\begin{array}{l}-0.002 \\
(0.001)\end{array}$ & $\begin{array}{l}0.000 \\
(0.001)\end{array}$ & $\begin{array}{l}0.002 \\
(0.001)\end{array}$ & $\begin{array}{l}-0.001 \\
(0.000)\end{array}$ \\
\hline $\log (p 8) \log (y)$ & $\begin{array}{l}0.006 \\
(0.001)\end{array}$ & $\begin{array}{l}-0.007 \\
(0.000)\end{array}$ & $\begin{array}{l}0.005 \\
(0.000)\end{array}$ & $\begin{array}{l}-0.002 \\
(0.001)\end{array}$ & $\begin{array}{l}0.001 \\
(0.000)\end{array}$ & $\begin{array}{l}0.010 \\
(0.001)\end{array}$ & $\begin{array}{l}0.002 \\
(0.001)\end{array}$ & $\begin{array}{c}-0.021 \\
(0.001)\end{array}$ & $\begin{array}{l}0.003 \\
(0.001)\end{array}$ \\
\hline $\log (p 9) \log (y)$ & $\begin{array}{l}0.006 \\
(0.001)\end{array}$ & $\begin{array}{l}0.005 \\
(0.000)\end{array}$ & $\begin{array}{l}0.001 \\
(0.000)\end{array}$ & $\begin{array}{c}-0.002 \\
(0.001)\end{array}$ & $\begin{array}{l}0.000 \\
(0.000)\end{array}$ & $\begin{array}{l}0.003 \\
(0.001)\end{array}$ & $\begin{array}{l}-0.001 \\
(0.000)\end{array}$ & $\begin{array}{l}0.003 \\
(0.001)\end{array}$ & $\begin{array}{l}-0.015 \\
(0.001)\end{array}$ \\
\hline
\end{tabular}

1:Food, 2:Housing, 3:Energy, 4:Transport, 5:Communication, 6:Leisure, 7:Clothes, 8:Health \& Edu 9:Appliances, 10: Others.

Household-specific price parameters are available from the authors upon request. The price of Others is used as the numeraire. We use the Stata routine developed in Pendakur (2009) to estimate the EASI demand system. 
Table 12

Iterated 3SLS (Continued)

\begin{tabular}{|c|c|c|c|c|c|c|c|c|c|}
\hline & $\begin{array}{l}w_{1} \\
\mathrm{~b} / \mathrm{se}\end{array}$ & $\begin{array}{l}w_{2} \\
\mathrm{~b} / \mathrm{se}\end{array}$ & $\begin{array}{l}w_{3} \\
\mathrm{~b} / \mathrm{se}\end{array}$ & $\begin{array}{l}w_{4} \\
\mathrm{~b} / \mathrm{se}\end{array}$ & $\begin{array}{l}w_{5} \\
\mathrm{~b} / \mathrm{se}\end{array}$ & $\begin{array}{l}w_{6} \\
\mathrm{~b} / \mathrm{se}\end{array}$ & $\begin{array}{l}w_{7} \\
\mathrm{~b} / \mathrm{se}\end{array}$ & $\begin{array}{l}w_{8} \\
\mathrm{~b} / \mathrm{se}\end{array}$ & $\begin{array}{l}w_{9} \\
\mathrm{~b} / \mathrm{se}\end{array}$ \\
\hline Central heating $(\mathrm{CH})$ & $\begin{array}{l}-0.005 \\
(0.001)\end{array}$ & $\begin{array}{l}0.008 \\
(0.001)\end{array}$ & $\begin{array}{l}-0.005 \\
(0.000)\end{array}$ & $\begin{array}{l}-0.006 \\
(0.001)\end{array}$ & $\begin{array}{l}0.001 \\
(0.000)\end{array}$ & $\begin{array}{l}0.008 \\
(0.001)\end{array}$ & $\begin{array}{l}0.004 \\
(0.000)\end{array}$ & $\begin{array}{l}-0.001 \\
(0.001)\end{array}$ & $\begin{array}{c}-0.002 \\
(0.001)\end{array}$ \\
\hline District heating $(\mathrm{DH})$ & $\begin{array}{l}-0.003 \\
(0.001)\end{array}$ & $\begin{array}{l}0.005 \\
(0.001)\end{array}$ & $\begin{array}{l}-0.006 \\
(0.000)\end{array}$ & $\begin{array}{c}-0.014 \\
(0.001)\end{array}$ & $\begin{array}{l}0.001 \\
(0.000)\end{array}$ & $\begin{array}{l}0.012 \\
(0.001)\end{array}$ & $\begin{array}{l}0.005 \\
(0.000)\end{array}$ & $\begin{array}{l}0.003 \\
(0.001)\end{array}$ & $\begin{array}{l}-0.001 \\
(0.001)\end{array}$ \\
\hline Building date 1948 & $\begin{array}{l}-0.010 \\
(0.000)\end{array}$ & $\begin{array}{l}-0.060 \\
(0.001)\end{array}$ & $\begin{array}{l}0.004 \\
(0.000)\end{array}$ & $\begin{array}{l}0.019 \\
(0.001)\end{array}$ & $\begin{array}{l}0.000 \\
(0.000)\end{array}$ & $\begin{array}{l}0.015 \\
(0.001)\end{array}$ & $\begin{array}{l}-0.001 \\
(0.000)\end{array}$ & $\begin{array}{l}0.019 \\
(0.001)\end{array}$ & $\begin{array}{l}0.009 \\
(0.001)\end{array}$ \\
\hline Building date 49 - 90 & $\begin{array}{l}-0.012 \\
(0.000)\end{array}$ & $\begin{array}{l}-0.048 \\
(0.001)\end{array}$ & $\begin{array}{l}0.001 \\
(0.000)\end{array}$ & $\begin{array}{l}0.015 \\
(0.001)\end{array}$ & $\begin{array}{l}-0.000 \\
(0.000)\end{array}$ & $\begin{array}{l}0.013 \\
(0.001)\end{array}$ & $\begin{array}{l}-0.002 \\
(0.000)\end{array}$ & $\begin{array}{l}0.019 \\
(0.001)\end{array}$ & $\begin{array}{l}0.009 \\
(0.000)\end{array}$ \\
\hline Dwelling size (Dsize) & $\begin{array}{l}-0.000 \\
(0.000)\end{array}$ & $\begin{array}{l}0.001 \\
(0.000)\end{array}$ & $\begin{array}{l}0.000 \\
(0.000)\end{array}$ & $\begin{array}{l}-0.000 \\
(0.000)\end{array}$ & $\begin{array}{l}-0.000 \\
(0.000)\end{array}$ & $\begin{array}{l}-0.000 \\
(0.000)\end{array}$ & $\begin{array}{l}-0.000 \\
(0.000)\end{array}$ & $\begin{array}{l}-0.000 \\
(0.000)\end{array}$ & $\begin{array}{c}-0.000 \\
(0.000)\end{array}$ \\
\hline Below 20k inhabitants & $\begin{array}{l}-0.000 \\
(0.000)\end{array}$ & $\begin{array}{l}-0.009 \\
(0.001)\end{array}$ & $\begin{array}{l}0.000 \\
(0.000)\end{array}$ & $\begin{array}{l}0.003 \\
(0.001)\end{array}$ & $\begin{array}{l}0.001 \\
(0.000)\end{array}$ & $\begin{array}{l}0.004 \\
(0.001)\end{array}$ & $\begin{array}{l}0.002 \\
(0.000)\end{array}$ & $\begin{array}{l}-0.001 \\
(0.001)\end{array}$ & $\begin{array}{c}-0.001 \\
(0.001)\end{array}$ \\
\hline $20 \mathrm{k}-10 \mathrm{k}$ inhabitants & -0.001 & -0.001 & -0.001 & -0.002 & 0.001 & 0.008 & 0.001 & -0.002 & -0.003 \\
\hline HDD & $\begin{array}{c}-0.000 \\
(0.000)\end{array}$ & $\begin{array}{l}-0.000 \\
(0.000)\end{array}$ & $\begin{array}{l}-0.000 \\
(0.000)\end{array}$ & $\begin{array}{l}-0.000 \\
(0.000)\end{array}$ & $\begin{array}{l}0.000 \\
(0.000)\end{array}$ & $\begin{array}{l}-0.000 \\
(0.000)\end{array}$ & $\begin{array}{l}0.000 \\
(0.000)\end{array}$ & $\begin{array}{l}0.000 \\
(0.000)\end{array}$ & $\begin{array}{l}0.000 \\
(0.000)\end{array}$ \\
\hline constant & $\begin{array}{l}-3.667 \\
(0.512)\end{array}$ & $\begin{array}{c}-14.469 \\
(0.705)\end{array}$ & $\begin{array}{l}-0.065 \\
(0.305)\end{array}$ & $\begin{array}{c}-5.052 \\
(0.832)\end{array}$ & $\begin{array}{l}0.133 \\
(0.167)\end{array}$ & $\begin{array}{l}12.717 \\
(0.882)\end{array}$ & $\begin{array}{l}0.430 \\
(0.351)\end{array}$ & $\begin{array}{l}9.064 \\
(0.663)\end{array}$ & $\begin{array}{l}1.399 \\
(0.603)\end{array}$ \\
\hline $\mathrm{N}$ & 122500 & & & & & & & & \\
\hline R-squared & 0.264 & 0.408 & 0.193 & 0.288 & 0.222 & 0.149 & 0.106 & 0.084 & 0.059 \\
\hline
\end{tabular}

1:Food, 2:Housing, 3:Energy, 4:Transport, 5:Communication, 6:Leisure, 7:Clothes, 8:Health \& Edu 9:Appliances, 10: Others.

Household-specific price parameters are available from the authors upon request. The price of Others is used as the numeraire. We use the Stata routine developed in Pendakur (2009) to estimate the EASI demand system. 